\title{
Activation of peroxyl and molecular oxygen using bis-benzimidazole diamide copper (II) compounds
}

\author{
PAVAN MATHUR \\ Department of Chemistry, University of Delhi, Delhi 110007 \\ e-mail: pavanmat@yahoo.co.in
}

\begin{abstract}
New tetradentate bis-benzimidazole ligands have been synthesized and utilized to prepare copper (II) complexes. Some of these copper (II) complexes have been characterized structurally. The copper (II) in these complexes is found to possess varying geometries. A distorted octahedral geometry is found with a highly unsymmetrical bidentate nitrate group. An unusual polymeric one-dimensional structure is observed where copper (II) is in a distorted square pyramidal geometry with a monodentate nitrate ion, having long $\mathrm{Cu}-\mathrm{O}$ bond, while a distorted triagonal bipyramidal geometry is found with two carbonyl $\mathrm{O}$ atoms and a $\mathrm{Cl}$ atom in the equatorial plane, and two benzimidazole imine $\mathrm{N}$ atoms occupy the axial position. These compounds are found to activate the cumylperoxyl group, and this has been utilized in the facile oxidation of aromatic alcohols to aldehydes, where they act as catalysts with large turnovers. The yields of the respective products vary from 32 to $65 \%$. The role of molecular oxygen has been studied and an attempt has been made to identify the "active copper species". Activation of molecular oxygen has also been observed and has been used for oxidative dealkylation of a hindered phenol, producing di-butyl quinones with yields of 20-25\% and 10-12 fold catalytic turnover. Dihydroxybenzenes and substituted catechols are also readily oxidized to the corresponding quinones, in oxygen-saturated solvents. Yields of $84 \%$ have been observed with 34-fold catalyst turnover, with di-t-butylcatechol. The activity of these copper (II) - bis-benzmidazolediamide compounds is reminiscent of the functioning of copper centres in galactose oxidase, tyrosinase and catechol oxidase.
\end{abstract}

Keywords. Copper(II); bis-benzimidazolediamide; galactose oxidase; catechol oxidase; tyrosinase.

\section{Introduction}

Oxidation reactions using molecular oxygen are of fundamental significance in living organisms. The ability of copper-containing metalloproteins to reversibly bind and activate dioxygen has been the focus of continued interest in bioinorganic chemistry. Tyrosinase is a copper-containing enzyme that contains two $\mathrm{Cu}(\mathrm{II})$ ions coupled via a magnetic exchange interaction. This coupled dinuclear $\mathrm{Cu}(\mathrm{II})$ site is also the resting state of the enzyme and is referred to as mettyrosinase. ${ }^{1}$ The enzyme functions via a deoxy site which has two copper ions in the +1 oxidation state. An oxytyrosinase form is generated when the deoxy site reacts with molecular oxygen. The oxytyrosinase hydroxylates monophenols to diphenols and in turn produces the met-tyrosinase form containing two $\mathrm{Cu}$ (II) ions. It is the met-tyrosinase form that is then further involved in the oxidation of diphenols to quinones, regenerating the deoxy site. This activity of mettyrosinase is similar to that of catechol oxidase from sweet potatoes ${ }^{2}$ while galactose oxidase (GO) is a fungal enzyme containing mononuclear copper ion, which catalyses the oxidation of primary alcohols to aldehydes, coupled to the two-electron reduction of $\mathrm{O}_{2}$ to $\mathrm{H}_{2} \mathrm{O}_{2}{ }^{3}$

In its catalytic cycle, a unique tyrosyl radical cofactor plays a vital role. ${ }^{4} \mathrm{The} \mathrm{Cu}(\mathrm{II})$ is located in a distorted square based pyramidal environment with a tyrosine in the apical position; Two histidines, Try-272, and an acetate ion form the $\mathrm{N}_{2} \mathrm{O}_{2}$ square planar geometry around the $\mathrm{Cu}(\mathrm{II})$ site. $^{5}$

Further there is interest in the research devoted to ligands bearing an amido group as they act as fundamental building blocks in many biomolecules. ${ }^{6} \mathrm{~A}$ number of ligands based on salicylamide ${ }^{7}$ and pyridine mono and diamide ${ }^{8}$ have been reported which resist oxidative degradation and afford very stable complexes with a vide range of metal ions. Interest in the use of chelating ligands incorporating benzimidazole as models for active sites in several copper containing proteins has also grown rapidly since imidazole of histidines was identified as one of the coordinating ligands in many of the copper-containing proteins.

Moreover, the catalytic oxidation and oxygenation of organic substrates by biomimetic metal complexes 
is equally important. Such complexes provide an alternate route to cleaner organic synthesis using molecular oxygen in place of toxic oxidizing agents.

We have therefore initiated a study of new bis(benzimidazole)-based diamide ligands, where the bound copper (II) is in a distorted five/six-coordinate environment with anodic $E_{1 / 2}$ values, ${ }^{9}$ and here we review this study. A series of new tetradentate diamide ligands $\mathrm{N}, \mathrm{N}^{\prime}$-bis (2-benzimidazolylmethyl) hexanediamide (GBHA), N, $\mathrm{N}^{\prime}$-bis(N-octyl-2-benzimidazolylmethyl) hexanediamide (O-GBHA) and N, $\mathrm{N}^{\prime}$ bis(2-benzimidazolylmethyl) 2,2'-oxy-diethaneamide have been synthesized and their $\mathrm{Cu}(\mathrm{II})$ complexes are reported. These have been found to carry out oxidation of various catechols and peroxidedependent facile oxidation of the aryl alcohols to aldehydes.

\section{Synthesis}

\section{$2.1 \quad N, N^{\prime}$-bis(2-benzimidazolylmethyl) hexanediamide (GBHA)}

This ligand was prepared following the procedure of Vagg et $a l^{10}$. To a solution of adipic acid $(1.67 \mathrm{~g}$, $11.4 \mathrm{mmol})$ in pyridine $(20 \mathrm{ml})$ was added a solution of glycine benzimidazole dihydrochloride $(5.0 \mathrm{~g}$, $22.8 \mathrm{mmol})$ in pyridine $(30 \mathrm{ml})$. The mixture was stirred gently for 10 min during which a white precipitate appeared. The reaction mixture was then heated slowly on a water bath at a temperature of $40^{\circ} \mathrm{C}$, and to it was added triphenyl phosphite $(7.08 \mathrm{ml}, 22.8 \mathrm{mmol})$ dropwise over a period of $15 \mathrm{~min}$. The reaction mixture was simultaneously stirred. After addition of $\mathrm{P}\left(\mathrm{OPh}_{3}\right)$ was complete and the initially formed white precipitate dissolved, the temperature of the reaction mixture was slowly raised to $75^{\circ} \mathrm{C}$ and the clear solution was stirred for $1 \mathrm{~h}$. A white solid resulted which was filtered off, washed with chloroform, and neutralized. The white crystalline product so obtained was recrystallised with a EtOH- $\mathrm{H}_{2} \mathrm{O}(1: 2)$ mixture and analysed for composition $\mathrm{C}_{22} \mathrm{H}_{24} \mathrm{~N}_{6} \mathrm{O}_{2} \cdot \mathrm{H}_{2} \mathrm{O}$.

Analysis: Found (calc): C 61.95 (62.16); H 6.14 (6.16); N 19.73 (19.90). m.p. $276^{\circ} \mathrm{C}$. Yield: $1.9 \mathrm{~g}$ $(41 \cdot 1 \%){ }^{1} \mathrm{H}-\mathrm{NMR}\left(d_{6}\right.$-DMSO): $\delta(\mathrm{ppm})=1.65$ (quin, $4 \mathrm{H}), 2 \cdot 26(t, 4 \mathrm{H}), 4 \cdot 54(d, 4 \mathrm{H}), 7 \cdot 15-7 \cdot 49(m, 8 \mathrm{H})$, $8.44\left(t, 2 \mathrm{H}_{\text {amide } \mathrm{NH}}\right), 12.07\left(s, b r, 2 \mathrm{H}_{\text {benzim NH}}\right), \mathrm{IR}(\mathrm{KBr}$ Pallets): $3296 \mathrm{~cm}^{-1}\left(v_{\mathrm{N}-\mathrm{H} \text { amide }}\right), 3185 \mathrm{~cm}^{-1}\left(v_{\mathrm{N}-\mathrm{H} \text { benzim }}\right)$, $1635 \mathrm{~cm}^{-1} \quad\left(v_{\mathrm{C}=\mathrm{O} \text { amide }}\right), 1539 \mathrm{~cm}^{-1}\left(v_{\mathrm{C}-\mathrm{N}}\right.$ amide $\left.\mathrm{II}\right)$, $1448 \mathrm{~cm}^{-1}\left(v_{\mathrm{C}=\mathrm{N}-\mathrm{C}=\mathrm{C} \text { benzim }}\right) . \Lambda_{\max }, \mathrm{nm}(\log \varepsilon)(\mathrm{MeOH})$ : 243 (3.67), $272(3 \cdot 68), 279(3 \cdot 68)$.

\section{$2.2 N, N^{\prime}$-bis(n-octyl-2-benzimidazolylmethyl)} hexanediamide (O-GBHA)

The N-octyl derivative of GBHA was synthesized by modifying the procedure of Reed et al. ${ }^{11}$

\section{$2.3 N, N^{\prime}$-bis(2-methylbenzimidazolyl)}

2,2'-oxydiethanamide (GBOA)

This ligand was prepared in a similar manner as GBHA except diglycollic acid was used instead of adipic acid. The reddish brown solution obtained was cooled down to room temperature, washed with saturated solution of sodium bicarbonate till all effervescence ceased and then washed twice with distilled water. Immediately a yellowish white solid appeared which was first washed with water and then with acetone to give white flaky solid, which was recrystallised using $\mathrm{EtOH}-\mathrm{H}_{2} \mathrm{O}(1: 2)$ and analysed for composition $\mathrm{C}_{20} \mathrm{H}_{20} \mathrm{~N}_{6} \mathrm{O}_{3} \cdot 2 \mathrm{H}_{2} \mathrm{O}$.

Analysis: Found (calc): C 56.06 (56.07), H 5.59 (5.61), N 19.78 (19.63)\%. m.p.: $125^{\circ} \mathrm{C}$, yield: $2.6 \mathrm{~g}$ $(59 \cdot 2 \%),{ }^{1} \mathrm{H}-\mathrm{NMR}\left(\mathrm{DMSO}-d_{6}\right): \delta(\mathrm{ppm})=4 \cdot 11(s, 4 \mathrm{H})$, $4 \cdot 57(d, 4 \mathrm{H}), 7 \cdot 11-7 \cdot 14(q, 4 \mathrm{H}), 7 \cdot 47-7 \cdot 50(q, 4 \mathrm{H})$, $8.73\left(t, 2 \mathrm{H}_{\text {amide } \mathrm{NH}}\right)$, IR bands $\left(\mathrm{cm}^{-1}, \mathrm{KBr}\right.$ pallets $)$ : $3203\left(v_{\mathrm{N}-\mathrm{H} \text { amide }}\right), 3158\left(v_{\mathrm{N}-\mathrm{H} \text { benzim }}\right), 1657\left(v_{\mathrm{C}=\mathrm{O} \text { amide } 1}\right)$, $1543\left(v_{\mathrm{C}-\mathrm{N} \text { amide II }}\right), 1446\left(v_{\mathrm{C}=\mathrm{N}-\mathrm{C}=\mathrm{C} \text { benzim }}\right), 1134\left(v_{\mathrm{C}-\mathrm{O}-\mathrm{C}}\right)$. $\lambda_{\max } \mathrm{nm}(\log \varepsilon)(\mathrm{MeOH}): 279$ (4.12), 272 (4.18), 247 (4.07), $\lambda_{\max } \mathrm{nm}(\log \varepsilon)\left(2: 8\right.$ DMSO: $\left.\mathrm{CH}_{3} \mathrm{CN}\right): 281$ (4.39), $277(4 \cdot 41)$.

\section{Synthesis of complexes}

\section{$3.1[\mathrm{CuCl}(\mathrm{GBHA})] \mathrm{Cl}$}

To a methanolic solution of $\mathrm{CuCl}_{2} \cdot 2 \mathrm{H}_{2} \mathrm{O}(0.5 \mathrm{mmol})$ was added a methanolic solution of the ligand $(0.5 \mathrm{mmol})$. The resulting parrot-green solution was stirred for $1 \mathrm{~h}$, after which the volume was reduced on a warm water bath. The parrot-green product obtained was washed with a small amount of methanol and air-dried. It was then redissolved in excess warm methanol, and the clear solution was left undisturbed for weeks to give beautiful green needles of the complex, suitable for $\mathrm{X}$-ray diffraction analysis. Crystals were analysed for the composition $\mathrm{CuC}_{22} \mathrm{H}_{24} \mathrm{~N}_{6} \mathrm{O}_{6}$ $\mathrm{Cl}_{2} \cdot \mathrm{H}_{2} \mathrm{O} \cdot \mathrm{CH}_{3} \mathrm{OH}$.

Analysis: Found (calc): C 46.72 (46.89); H 5.05 $(5 \cdot 10)$; N 14.40 (14.27)\%. $\lambda_{\max }, \mathrm{nm}(\log \varepsilon)(\mathrm{MeOH})$ : $758(2 \cdot 05), 360(s h), 277(4 \cdot 16), 271(4 \cdot 18) . \mu_{\mathrm{eff}}\left(\mu_{\mathrm{B}}\right)=$ 1.90. $E_{1 / 2}(V)=+0 \cdot 584$ vs NHE. IR $\left(\mathrm{cm}^{-1}, \mathrm{KBr}\right)$; 
$3395\left(v_{\mathrm{N}-\mathrm{H} \text { amide }}\right), 3209\left(v_{\mathrm{N}-\mathrm{H} \text { benzim }}\right), 1604$ (amide 1$)$, 1560 (amide II), $1452\left(v_{\mathrm{C}=\mathrm{N}-\mathrm{C}=\mathrm{C}}\right)$.

\section{$3.2\left[\mathrm{Cu}\left(\mathrm{NO}_{3}\right)(\mathrm{GBHA})\right]\left(\mathrm{NO}_{3}\right)$}

This complex was prepared in the same manner taking $\mathrm{Cu}\left(\mathrm{NO}_{3}\right)_{2} \cdot 3 \mathrm{H}_{2} \mathrm{O}$ in place of $\mathrm{CuCl}_{2} \cdot \mathrm{H}_{2} \mathrm{O}$. The green product was washed with methanol, dried in air, and analysed for the composition $\mathrm{CuC}_{22} \mathrm{H}_{24} \mathrm{~N}_{8} \mathrm{O}_{8}$. $0 \cdot 5 \mathrm{H}_{2} \mathrm{O} \cdot 0 \cdot 5 \mathrm{CH}_{3} \mathrm{OH}$.

Analysis: Found (calc): C 43.81 (43.79); H 4.33 (4.38); N 18.30 (18.17)\%. $\lambda_{\max }, \mathrm{nm}(\log \varepsilon)(\mathrm{MeOH})$ : 782 (1.94), $347(s h), 277$ (4.28), 270 (4.30). $\mu_{\text {eff }}$ $\left(\mu_{\mathrm{B}}\right)=2 \cdot 04 . E_{1 / 2}(V)=+0 \cdot 599$ vs NHE. IR $\left(\mathrm{cm}^{-1}\right.$, $\mathrm{KBr}) ; 3230\left(v_{\mathrm{N}-\mathrm{H} \text { amide }}\right), 3097$ ( $\left.v_{\mathrm{N}-\mathrm{H} \text { benzim }}\right), 1602$ (amide 1), 1501 (amide II), 1445 ( $\left.v_{\mathrm{C}=\mathrm{N}-\mathrm{C}=\mathrm{C}}\right), 1384$ and 821 $\left(v_{\mathrm{O}-\mathrm{N}-\mathrm{O} \text { sym and antisym }}\right)$.

\section{$3.3\left[\mathrm{Cu}\left(\mathrm{NO}_{3}\right)(\mathrm{GBHA})\right]$}

To a methanolic solution (10 ml) of GBHA $(0.5 \mathrm{mmol})$ was added a methanolic solution $(5 \mathrm{ml})$ of $\mathrm{Cu}$ $\left(\mathrm{NO}_{3}\right)_{2} \cdot 3 \mathrm{H}_{2} \mathrm{O}(0.5 \mathrm{mmol})$. The resulting parrot-green solution was stirred for $1 \mathrm{~h}$ in a septum-sealed threeneck flask. A solution of quinol $(0.5 \mathrm{mmol})$ was prepared in methanol $(10 \mathrm{ml})$. High purity dry nitrogen was then bubbled through both the solutions for $30 \mathrm{~min}$. The quinol solution was then transferred under nitrogen, via a double-end needle, to the copper (II) complex solution. An immediate colour change from green to yellow was observed. Stirring for 10 $15 \mathrm{~min}$ resulted in a white solid that was filtered off, washed several times with methanol, and dried in vacuo.

Analysis: Found (calc) for $\mathrm{CuC}_{22} \mathrm{H}_{24} \mathrm{~N}_{7} \mathrm{O}_{5}$. 0.7 $\mathrm{CH}_{3} \mathrm{OH}$. C 49.63 (49.32); $\mathrm{H} 4.77$ (4.88); N 17.61 $(17 \cdot 70) \% . E_{1 / 2}(V)=+0.622$ vs NHE. IR $\left(\mathrm{cm}^{-1}, \mathrm{KBr}\right)$; $3275\left(v_{\mathrm{N}-\mathrm{H} \text { amide }}\right), 3195\left(v_{\mathrm{N}-\mathrm{H} \text { benzim) }}, 1653\right.$ (amide 1$)$, 1538 (amide II), $1459\left(v_{\mathrm{C}=\mathrm{N}-\mathrm{C}=\mathrm{C}}\right), 1384$ and 821 $\left(v_{\mathrm{O}-\mathrm{N}-\mathrm{Osym} \text { and antisym }}\right) .{ }^{1} \mathrm{H}-\mathrm{NMR}$ of freshly precipitated $\left[\mathrm{Cu}\left(\mathrm{NO}_{3}\right)-(\mathrm{GBHA})\right]$ (slightly wet with methanol) in $d_{6}$-DMSO: $\delta(\mathrm{ppm})=1.54$ (quin, $\left.b r, 4 \mathrm{H}\right), 2.21(t, b r$, $4 \mathrm{H}), 4.73(d, b r, 4 \mathrm{H}), 7.30-7.86(m, b r, 8 \mathrm{H}), 8.83(t, b r$, $\left.2 \mathrm{H}_{\text {amide } \mathrm{NH}}\right)$.

\section{$3.4\left[\mathrm{CuCl}_{2}(\mathrm{GBOA})\right]$}

This was prepared in the same manner as the chloride complex of GBHA. The olive-green product was filtered, washed with small amounts of ethanol and air-dried. The product was recrystallized from hot ethanol and analysed for the composition $\mathrm{CuC}_{20} \mathrm{H}_{20} \mathrm{~N}_{6} \mathrm{O}_{3} \mathrm{Cl}_{2} \cdot 2 \mathrm{H}_{2} \mathrm{O}$ Yield: $200 \mathrm{mg}(70 \%)$.

Analysis: Found (calc): C 42.35 (42.67), H 4.24 (4.27), $\mathrm{N} 14.85(14.93) \%, \lambda_{\max } \mathrm{nm}(\log \varepsilon)(2: 8$ DMSO : $\left.\mathrm{CH}_{3} \mathrm{CN}\right): 780$ (1.93), 378 (2.77), $279(4 \cdot 10)$, $272(4 \cdot 14), \mu_{\text {eff }}(\mathrm{BM}): 1 \cdot 82 ; E_{1 / 2}(\mathrm{~V}):+0 \cdot 574 \mathrm{~V}$ vs NHE. IR bands $\left(\mathrm{cm}^{-1}, \mathrm{KBr}\right.$ pallets): $3258\left(v_{\mathrm{N}-\mathrm{H} \text { amide }}\right)$, $1654\left(v_{\text {amide }}\right), 1542\left(v_{\text {amide II }}\right), 1457\left(v_{\mathrm{C}=\mathrm{N}-\mathrm{C}=\mathrm{C}}\right)$. Crystals suitable for X-ray diffraction analysis were grown by dissolving the green complex in warm ethanol, layering it with acetone and leaving the solution for a few weeks to obtain green needles of the complex.

\section{$3.5\left[\mathrm{Cu}^{l}\left(\mathrm{NO}_{3}\right)(\mathrm{GBOA})\right]$}

This was prepared in the same manner as $\left[\mathrm{Cu}^{\mathrm{I}}\right.$ $\left(\mathrm{NO}_{3}\right)$ GBHA]. The product was analysed for the composition $\mathrm{CuC}_{20} \mathrm{H}_{20} \mathrm{~N}_{7} \mathrm{O}_{6} \cdot 0 \cdot 5 \mathrm{H}_{2} \mathrm{O}$. Yield: $170 \mathrm{mg}$ $(65 \%)$.

Analysis: Found (calc): C $45 \cdot 55$ (45.58), H 4.00 (3.99), N 18.60 (18.61)\%, $E_{1 / 2}(V):+0.395 \mathrm{~V}$ vs NHE. $\lambda_{\max } \mathrm{nm}(\log \varepsilon)$ (DMSO): 279 (4.12), $272(4 \cdot 17)$. IR bands $\left(\mathrm{cm}^{-1}, \mathrm{KBr}\right.$ pallets $): 3238$ ( $\left.v_{\mathrm{N}-\mathrm{H} \text { amide }}\right), 3111$ $\left(v_{\mathrm{N}-\mathrm{H} \text { benzim }}\right), 1649$ ( $\left.v_{\text {amide I }}\right), 1541$ ( $\left.v_{\text {amide II }}\right), 1458$ $\left(v_{\mathrm{C}=\mathrm{N}-\mathrm{C}=\mathrm{C}}\right), 1384$ and $821\left(v_{\mathrm{O}-\mathrm{N}-\mathrm{O} \text { sym and antisym }}\right){ }^{1} \mathrm{H}-\mathrm{NMR}$ of freshly precipitated $\left[\mathrm{Cu}^{1}\left(\mathrm{NO}_{3}\right)(\mathrm{GBOA})\right]$ (slightly wet with methanol) (DMSO- $\left.d_{6}\right): \delta(\mathrm{ppm})=4 \cdot 11(s, b r$, $4 \mathrm{H}), 4 \cdot 37(s, b r, 4 \mathrm{H}), 7 \cdot 34(s, b r, 4 \mathrm{H}), 7 \cdot 84(s, b r, 4 \mathrm{H})$, $9 \cdot 07\left(s, 2 \mathrm{H}_{\text {amide } \mathrm{NH}}\right)$.

The same product was obtained when the reducing agent was altered from quinol to ascorbic acid and to dihydroxyacetophenone. Similarity of the products was confirmed by analytical data and ${ }^{1} \mathrm{H}-\mathrm{NMR}$ spectra.

\section{$3.6\left[\mathrm{Cu}(\mathrm{O}-\mathrm{GBHA})\left(\mathrm{NO}_{3}\right)\right]\left(\mathrm{NO}_{3}\right)$}

This was prepared by a procedure similar to that used for the above complex, by taking $\mathrm{Cu}\left(\mathrm{NO}_{3}\right)_{2}$. $3 \mathrm{H}_{2} \mathrm{O}$ in place of $\mathrm{CuCl}_{2} \cdot 2 \mathrm{H}_{2} \mathrm{O}$. The bright-green complex obtained was air-dried. The complex was redissolved in $\mathrm{CHCl}_{3}: \mathrm{MeOH}(5: 1, \mathrm{v} / \mathrm{v})$ and was layered with petroleum ether. The clear solution was left undisturbed for weeks to give green crystals, suitable for X-ray diffraction work. The complex was analysed for the composition $\mathrm{CuC}_{38} \mathrm{H}_{56} \mathrm{~N}_{6} \mathrm{O}_{2}\left(\mathrm{NO}_{3}\right)_{2}$.

Analysis: Found (calc): C 56.24 (55.91), H 6.91 (6.86), N 13.86 (13.73)\%, $\lambda_{\max } \mathrm{nm}(\log \varepsilon) 275(4 \cdot 12)$, 283 (4.06), 740 (1.95). 


\section{Structural details}

\section{$4.1[\mathrm{CuCl}(\mathrm{GBHA})] \mathrm{Cl} \cdot \mathrm{H}_{2} \mathrm{O} \cdot \mathrm{CH}_{3} \mathrm{OH}$}

The structure is shown in figures 1 and 2. The crystals are stable only in mother liquor and tend to become opaque when taken out. Crystals have the space group $C 2 / c$ of a monoclinic system. The coordinate environment around the copper atom is pentacoordinate consisting of two benzimidazolyl nitrogen atoms, two amide carbonyl oxygen atoms, and a chloride ion. The structure has the appearance of a trigonal bipyramid in which equatorial positions are occupied by a $\mathrm{Cl}$ atom and amide carbonyl oxygen atoms $\mathrm{O}(1)$ and $\mathrm{O}(2)$, and the axial positions by benzimidazole imine nitrogen atoms $\mathrm{N}(1 \mathrm{~A})$ and $\mathrm{N}(1 \mathrm{~B}) . \mathrm{Cu}-$ $\mathrm{N}$ bond distances of $1.967 \AA(\mathrm{Cu}-\mathrm{N}(1 \mathrm{~A}))$ and $1.977 \AA(\mathrm{Cu}-\mathrm{N}(1 \mathrm{~B}))$ are in the range found for similar benzimidazole and imidazole ligated compounds ${ }^{12}$. $\mathrm{Cu}-\mathrm{O}$ bond distances of $2 \cdot 111 \AA(\mathrm{Cu}-\mathrm{O}(1))$ and $2 \cdot 166 \AA(\mathrm{Cu}-\mathrm{O}(2))$ are considerably longer than those reported in the literature for amide carbonyl coordination. $^{13}$

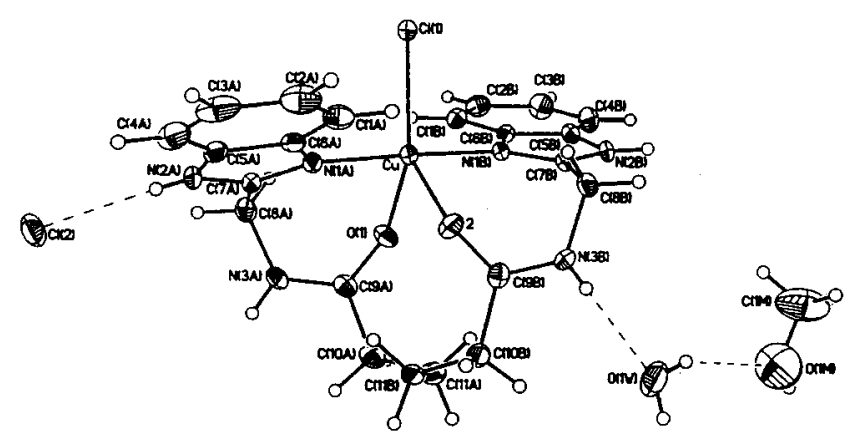

Figure 1. ORTEP projection of $[\mathrm{Cu}(\mathrm{GBHA}) \mathrm{Cl}] \mathrm{Cl}_{2} \mathrm{H}_{2} \mathrm{O}$ $\mathrm{CH}_{3} \mathrm{OH}$ showing the atomic numbering scheme.

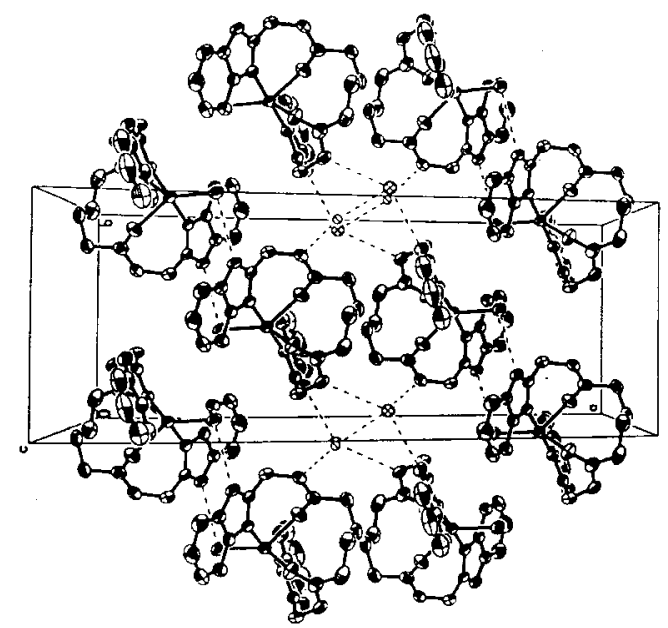

Figure 2. Stereo drawing of the unit cell contents of $[\mathrm{Cu}(\mathrm{GBHA}) \mathrm{Cl}]-\mathrm{Cl} \cdot \mathrm{H}_{2} \mathrm{O}-\mathrm{CH}_{3} \mathrm{OH}$.
In pentacoordinated systems, the actual geometry of the complex can be described by a structural index parameter $\tau$ such that $\tau=\beta-\alpha / 60^{\circ}$, where $\beta$ and $\alpha$ are the two largest angles $(\beta>\alpha)$. According to this model, out of the equatorial ligands (A, D, E), A is chosen such that the $\mathrm{Cu}-\mathrm{A}$ bond length is longer than $\mathrm{Cu}-\mathrm{D} / \mathrm{E}$ and should not be any one of the four donor atoms forming the two largest angles. Thus, the geometric parameter $\tau$ is applicable to pentacoordinated structures as an index of the degree of trigonality, within the structural continuum between trigonal bipyramidal (TBP) $\left(\beta-\alpha=60^{\circ}, \tau=1\right)$ and square pyramidal $\left(\beta-\alpha=0^{\circ}, \tau=0\right)$. The complex has a $\tau=0.591$, indicating a distortion from the perfect TBP towards distorted TBP. This complex does not fit the above described model fully, since the $\mathrm{Cu}-(2)$ $(\mathrm{Cu}-\mathrm{A})$ bond length of $2.166 \AA$ is shorter than the $\mathrm{Cu}-\mathrm{Cl}(1)(\mathrm{Cu}-\mathrm{D} / \mathrm{E})$ bond length of $2.3082 \AA$. This observed $\mathrm{Cu}-\mathrm{Cl}(1)$ is in the range similar to that observed for similar pentacoordinated $\mathrm{Cu}$ (II) compounds ${ }^{14}$. This coordinated $\mathrm{Cl}$ atom is also hydrogenbonded to the benzimidazole $\mathrm{NH}$ of the neighbouring complex molecule. Equatorial angle deviates largely from the expected value of $120^{\circ}$, the largest deviation being $24.79^{\circ}$, whereas $\mathrm{N}(1 \mathrm{~A})-\mathrm{Cu}-\mathrm{N}(1 \mathrm{~B})$ is $176 \cdot 89(13)^{\circ}$. The sum of equitorial angles at $\mathrm{Cu}$ is $359.95^{\circ}$, showing that the metal ion is essentially in the mean plane of the equatorial donors. The crystal consists of layers of $[\mathrm{CuCl}(\mathrm{GBHA})] \mathrm{Cl} \cdot \mathrm{H}_{2} \mathrm{O} \cdot \mathrm{CH}_{3} \mathrm{OH}$ stacked over one another, held together by $\mathrm{NH}_{\text {amide }} \ldots \mathrm{O}_{\text {water }}$ and $\mathrm{NH}_{\text {amide }} \ldots$ $\mathrm{O}_{\mathrm{MeOH}}$ interactions, whereas molecules within the layers are $\mathrm{H}$-bonded to each other via $\mathrm{NH}_{\text {benim }} . . \mathrm{Cl}$ bonds.

\section{$4.2\left[\mathrm{CuCl} l_{2}(\mathrm{GBOA})\right]$}

The structure is shown in figure 3 . The $\mathrm{Cu}(\mathrm{II})$ ion is surrounded by two nitrogen atoms (N2 and N6), two

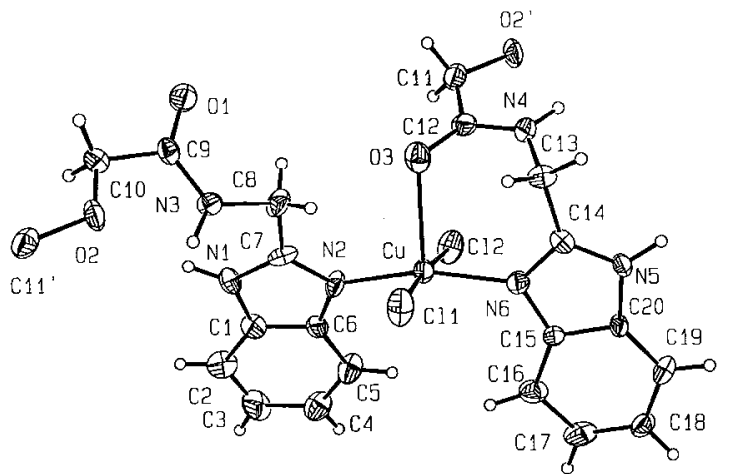

Figure 3. ORTEP projection of $\left[\mathrm{Cu}(\mathrm{GBOA}) \mathrm{Cl}_{2}\right]$ showing the atomic numbering scheme. 
chlorine atoms ( $\mathrm{Cl1}$ and $\mathrm{Cl} 2)$ and one oxygen atom occupying the vertex of a square-based pyramid. Two trans-bonded chlorine atoms (Cl1 and Cl2) and nitrogens (N1 and N6) form the equatorial plane. The apical position is occupied by the oxygen atom (O3) of an amide carbonyl group. It is a onedimensional polymer structure with the bonding scheme: ...Cu...ligand... Cu...ligand - such that the two benzimidazole units coordinated to a given $\mathrm{Cu}(\mathrm{II})$ ion are from different ends of two different molecules of the ligand.

The equatorial $\mathrm{Cu}-\mathrm{N}$ bond distances of $1.968 \AA$ $(\mathrm{Cu}-\mathrm{N}(2))$ and $1.985 \AA(\mathrm{Cu}-\mathrm{N}(6))$ are in the range found for similar benzimidazole and imidazole-ligated compounds. ${ }^{12,15}$ These are only slightly longer than those of GBHA ligated copper complex $\mathrm{CuCl}_{2} \mathrm{GBHA}$. $\mathrm{Cu}-\mathrm{Cl}$ bond distances of $2.362 \AA(\mathrm{Cu}-\mathrm{Cl}(1))$ and $2.336 \AA(\mathrm{Cu}-\mathrm{Cl}(2))$ are in the range reported for compounds containing equatorially bound chlorine atoms.

The axial $\mathrm{Cu}-\mathrm{O} 3$ bond length of $2 \cdot 390 \AA$ is considerably longer than those reported in the literature for $\mathrm{Cu}$ (II) complexes having axial oxygen coordination. The complex has a $\tau$ value of $0 \cdot 167\left(\tau=\beta-\alpha / 60^{\circ}\right)$ where $\alpha=\mathrm{N} 2-\mathrm{Cu}-\mathrm{N} 6=164 \cdot 5^{\circ}$ and $\beta=\mathrm{Cl} 2-\mathrm{Cu}-\mathrm{Cl} 1=$ $174.52^{\circ}$, indicating square pyramidal geometry with a small trigonal component. The equatorial angles deviate slightly from the expected value of $90^{\circ}$, the maximum deviation being $2 \cdot 6^{\circ}$. Two trans chlorine atoms are at an angle of $174.52^{\circ}$ and the trans nitrogen atoms are not completely linear, the N2$\mathrm{Cu}-\mathrm{N} 6$ bond angle being $164 \cdot 5^{\circ}$. The bonding of N2$\mathrm{Cu}-\mathrm{N} 6$ axis indicates that the two benzimidazole rings are not on the same plane. The sum of equatorial bond angles is $358.8^{\circ}$ indicating that $\mathrm{Cu}(\mathrm{II})$ atoms mainly reside in the square plane with only slight displacement above the plane towards apical oxygen. The apical $\mathrm{Cu}-\mathrm{O}$ bond is also not perpendicular to the square plane, the angles $\mathrm{O} 3-\mathrm{Cu}-\mathrm{N} 2$, $\mathrm{O} 3-\mathrm{Cu}-\mathrm{N} 6$ and $\mathrm{O} 3-\mathrm{Cu}-\mathrm{Cl} 1$ being about $97^{\circ}$. On an average, the lengthening of $\mathrm{Cu}-\mathrm{N}$ and $\mathrm{Cu}-\mathrm{O}$ bonds in $\mathrm{CuCl}_{2} \mathrm{GBOA}$ can be correlated with the reduced flexibility of the ligand due to shortening of the chain compared to GBHA, as a result of which the closer approach of donor to metal ion is slightly hindered. This also results in ligand-bridged mode structure of these complexes. The expanded angles indicate the displacement of equatorial atoms away from the apical oxygen. Crystals of the $\mathrm{Cu}(\mathrm{I})$ complex could not be grown despite our best efforts.

\section{$4.3\left[\mathrm{Cu}\left(\mathrm{NO}_{3}\right)(\mathrm{O}-\mathrm{GBHA})\right]\left(\mathrm{NO}_{3}\right)$}

The structure is shown in figure 4. The copper centre in the complex has tetragonally distorted octahedral environment. The six-coordination centre comprises two imine nitrogens of the two benzimidazole rings, two amide oxygens of the ligand and two oxygens of one of the nitrate anions. The carbonyl oxygen atom $\mathrm{O} 2$, nitrate oxygen atom $\mathrm{O} 3$, and the two benzimidazole imine nitrogen atoms $\mathrm{N} 4$ and $\mathrm{N} 5$ occupy the equatorial positions of the plane while the axial positions are occupied by another amide carbonyl oxygen atom $\mathrm{O} 1$ and nitrate oxygen atom $\mathrm{O} 5$ in distorted octahedral geometry. Bond lengths show that the nitrate group behaves as a highly unsymmetrical bidentate chelating ligand, with $\mathrm{Cu}-\mathrm{O} 5$ bond length $2.46 \AA$ much longer than $\mathrm{Cu}-\mathrm{O} 3$ bond length $2 \cdot 074 \AA$. The bond angle O3-Cu-O5 $55 \cdot 1(8)^{\circ}$ is in the range found for weakly coordinating bidentate ligands. The $\mathrm{Cu}-\mathrm{N}$ bond distances of $1.983 \AA(\mathrm{Cu}-$ N4) and $1.973 \AA(\mathrm{Cu}-\mathrm{N} 5)$ are found to be similar to those reported typically with imidazole/benzimidazole $\mathrm{N}$-atoms in the equatorial plane. ${ }^{12,15}$ Thus, the short distances in the present $\mathrm{Cu}$ (II) complex probably reflect that the overall positive charge on the complex is not fully compensated by the unsymmetrical bidentate nitrate ligand as compared to those complexes with good coordinating anions. The $\mathrm{Cu}-\mathrm{O}$ bond distances of $2.020 \AA(\mathrm{Cu}-\mathrm{O} 2)$ and $2.212 \AA(\mathrm{Cu}-\mathrm{O} 1)$ are considerably longer than those reported in the literature for amide carbonyl coordination. The bond angles are quite close to the values expected for an octahedral structure except for $\mathrm{O} 1-\mathrm{Cu}-\mathrm{O} 5156 \cdot 5(7)^{\circ}$ and $\mathrm{O} 3-\mathrm{Cu}-\mathrm{O} 555 \cdot 1(8)^{\circ}$ which are on the smaller side. The distortion may be due to the combined influence of the Jahn-Teller effect and the fixed bite size of the $\mathrm{NO}_{3}^{-}$ion. The atoms $\mathrm{O} 1, \mathrm{O} 2, \mathrm{O} 3, \mathrm{O} 5$ and $\mathrm{O} 2, \mathrm{O} 3$, N4, N5 lie in approximate planes with minimum deviation of $\mathrm{O} 5$ being $0.05 \AA$ for 05 . These three planes

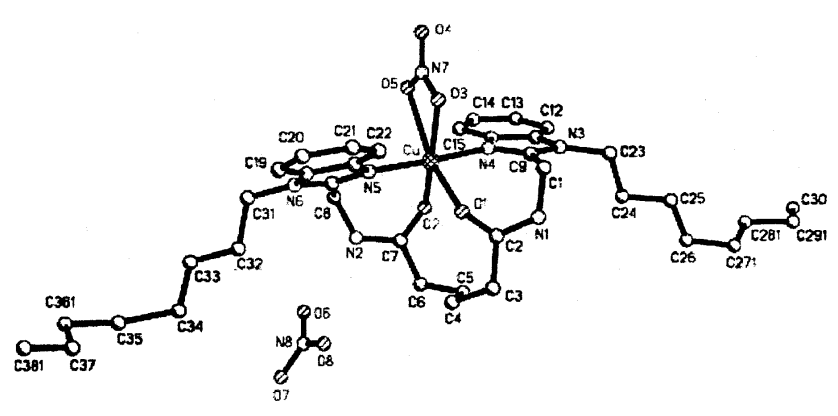

Figure 4. ORTEP view of $\left[\mathrm{Cu}(\mathrm{O}-\mathrm{GBHA})\left(\mathrm{NO}_{3}\right)\right]\left(\mathrm{NO}_{3}\right)$ showing the rotation about the $\mathrm{C} 3-\mathrm{C} 4-\mathrm{C} 5-\mathrm{C} 6$ bond. 
are almost perpendicular to each other; the dihedral angles between the first and second and first and third are 85.5 (3) and $86.7(3)^{\circ}$ respectively, whereas between the first and third is $76 \cdot 9(4)^{\circ}$. Two benzimidazole rings are planar and have a dihedral angle of $29.4(3)^{\circ}$ with respect to each other. Torsional angles $\left(\mathrm{Cu}-\mathrm{N} 4-\mathrm{C} 10-\mathrm{C} 15,8^{\circ}\right.$; $\mathrm{Cu}-\mathrm{N} 5-\mathrm{C} 17-\mathrm{C} 22,6^{\circ}(3)^{\prime}$ also N4-C10-C15-C44, 179(2) ${ }^{\circ}$; N5-C17-C22$\mathrm{C} 21,-178(2)^{\circ}$ show that the two benzimidazole rings are projected in opposite directions to each other. The conformation of the chain joining the two benzimidazole rings may be defined as gaagagaag. A kink at C3-C4-C5-C6 gives a spiral turn to the ligand, and it wraps around the metal ion in the form of a half helix. The packing of the molecule shows an extensive hydrogen-bonding network. It involves intramolecular hydrogen bonds between amide nitrogen $\mathrm{N} 2$ and N6 and N8 of the free nitrate group. The second amide nitrogen $\mathrm{N} 1$ gives two strong intermolecular $\mathrm{H}$ bonds with $\mathrm{O} 7$ and $\mathrm{N} 8$ of the symmetry related uncoordinated nitrate group. Apart from these, there are a number of weak $\mathrm{C}-\mathrm{H}$...O and $\mathrm{C}-\mathrm{H} \ldots \mathrm{N} \mathrm{H}-$ bonding interactions involving both the nitrate ions and various methylene and phenylene carbons.

\section{$4.4\left[\mathrm{Cu}\left(\mathrm{NO}_{3}\right)(\mathrm{GBHA})\right]\left(\mathrm{NO}_{3}\right) \cdot \mathrm{CH}_{3} \mathrm{OH}$}

The crystal structure of the compound is shown in figure 5. It consists of discrete monomeric units composed of a cationic copper complex and a nitrate anion. The coordination geometry around the $\mathrm{Cu}(\mathrm{II})$

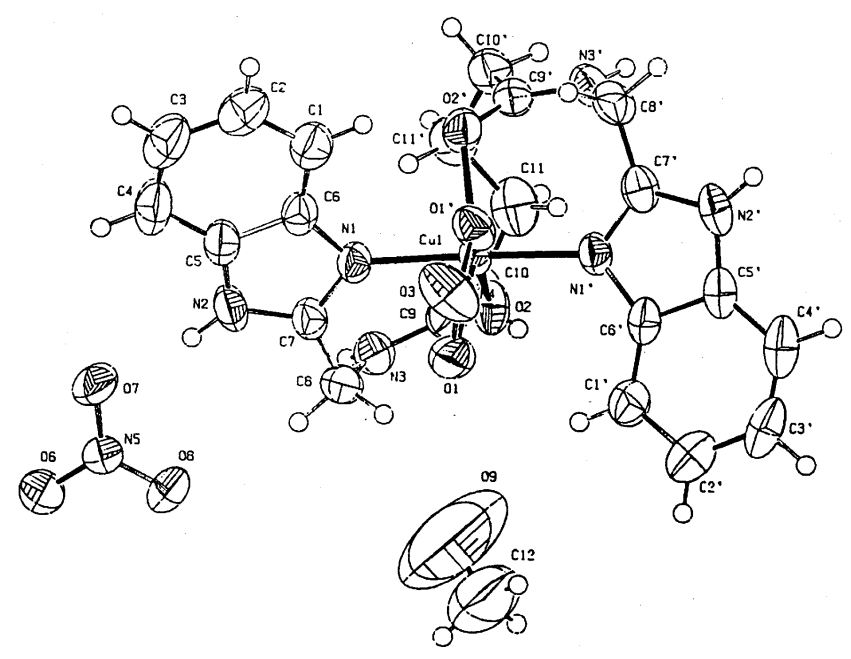

Figure 5. ORTEP projection of $\left[\mathrm{Cu}(\mathrm{GBHA})\left(\mathrm{NO}_{3}\right)\right]$ $\left(\mathrm{NO}_{3}\right) \cdot \mathrm{CH}_{3} \mathrm{OH}$ showing atomic numbering scheme. ion is distorted square pyramidal with benzimidazole imine nitrogen atoms, carbonyl oxygen atoms and nitrate oxygen atom occupying the vertices. Two trans bonded benzimidazole nitrogen atoms ( $\mathrm{N} 1$ and $\mathrm{N1}^{\prime}$ ), an amide carbonyl oxygen atom (O2) and a nitrate oxygen atom $\left(\mathrm{O} 1^{\prime}\right)$, form the square plane while the pyramid is completed by second amide carbonyl oxygen $\left(\mathrm{O}^{\prime}\right)$. The $\mathrm{Cu}-\mathrm{N}_{\text {benzim }}$ distances of $1.973 \AA[\mathrm{Cu}-\mathrm{N}(1)]$ and $1.975 \AA[\mathrm{Cu}-\mathrm{N}(2)]$ are in the range found for similar complexes. $\mathrm{Cu}-\mathrm{O}$ distance of $1.992 \AA$ for equatorially bound carbonyl oxygen is in the expected range while the $\mathrm{Cu}-\mathrm{O}$ bond distance of $2.229 \AA$ for axially bound carbonyl oxygen is considerably longer than those reported in literature. ${ }^{13}$ The nitrate ion coordinates to $\mathrm{Cu}(\mathrm{II})$ in monodentate fashion through $\mathrm{O}^{\prime}$. N4-O1' bond length $(1.267 \AA)$ for nitrate is longer than the two N4-O1 and N4-O3 bonds of nitrate. The lengthening of this bond as compared to remaining two bonds is expected because of transfer of electron density from oxygen to $\mathrm{Cu}$ (II) and weakening of the $\mathrm{N} 4-\mathrm{Ol}^{\prime}$ bond. The $\mathrm{Cu}-\mathrm{O} 1^{\prime}$ bond length of $2.061 \AA$ is well close to the literature value of $2.000 \AA$. Bond angles of axial oxygen with equatorial atoms indicate a distortion of the equatorial plane away from axial oxygen. Thus $\mathrm{O} 2, \mathrm{~N}^{\prime}$, $\mathrm{O} 1^{\prime}$ are displaced below the equatorial plane while $\mathrm{N} 1$ is displaced above the plane. Coordination of one amide oxygen at axial position indicates that two symmetrical halves of the ligand may be in different planes. The actual geometry of the five-coordinated complex is described by the geometric parameter $\tau$ which is defined as an index of degree of trigonality, within the structural continuum between triagonal bipyramidal $(\tau=1)$ and square pyramidal $(\tau=0)$ such that $\left(\tau=\beta-\alpha / 60^{\circ}\right)$ where $\beta$ and $\alpha$ are the two largest angles $(\beta>\alpha)$. $\tau$ value for this complex comes out to be $0 \cdot 168$ indicating the slight distortion of square pyramidal geometry.

\section{5. ${ }^{1}$ H NMR, electronic spectrosopy, and cyclic voltammetry}

The electronic spectra of all the complexes were measured in methanol. UV bands at 272 and $279 \mathrm{~nm}$ are observed for the free ligand GBHA. These bands are characteristic of the benzimidazole group and arise from a $\pi \rightarrow \pi^{*}$ transition. All the complexes display a broad $d-d$ band in the region 740-790 nm characteristic of tetragonal geometry. A shoulder due to a LMCT (imidazole $\pi_{1} \mathrm{Cu}^{2+}$ ) band in the region $340-390 \mathrm{~nm}$ is also observed. The UV band in the 
complexes corresponding to a $\pi \rightarrow \pi^{*}$ transition shows enhanced absorption as indicated by their extinction coefficients.

The ${ }^{1} \mathrm{H}-\mathrm{NMR}$ spectrum of the free ligand GBHA (figure 6a) shows signals for aliphatic and aromatic protons with theoretically predicted splittings. A symmetrical multiplet in the range $7 \cdot 15-7 \cdot 49 \mathrm{ppm}$ arises due to benzimidazole ring protons characteristic of an $\mathrm{AA}^{\prime \prime} \mathrm{BB}^{\prime \prime}$ pattern. A triplet at $8.44 \mathrm{ppm}$ arises due to amide $\mathrm{NH}$ protons (coupled with adjacent $\mathrm{CH}_{2}$ protons (C) $(J=5.5 \mathrm{~Hz})$. Benzimidazole $\mathrm{NH}$ protons give a broad signal at $12.07 \mathrm{ppm}$. In the $\mathrm{Cu}(\mathrm{I})$ complex the aromatic ligand proton resonances are observed in two groups with a $1: 3$ proton ratio (figure $6 b$ ), unlike in GBHA where both the signals have the same proton integration. In the $\mathrm{Cu}(\mathrm{I})$ complex, the three aromatic protons $\left(\mathrm{H}_{5}, \mathrm{H}_{6}, \mathrm{H}_{7}\right)$ remain at the chemical shift close to that observed in the free ligand GBHA, while proton $\mathrm{H}_{4}$ is shifted downfield, being nearest to the imidazole $\mathrm{N}$ atom bound to $\mathrm{Cu}(\mathrm{I})$. The signals are slightly broadened possibly due to the presence of trace $\mathrm{Cu}$ (II) ions. In copper (I) complex of $[\mathrm{CuCl}$ (GBOA)] (figure 7), slightly shifted and broadened signals were observed for all ligand protons with expected integration. ${ }^{1} \mathrm{H}$ signals here are downfield

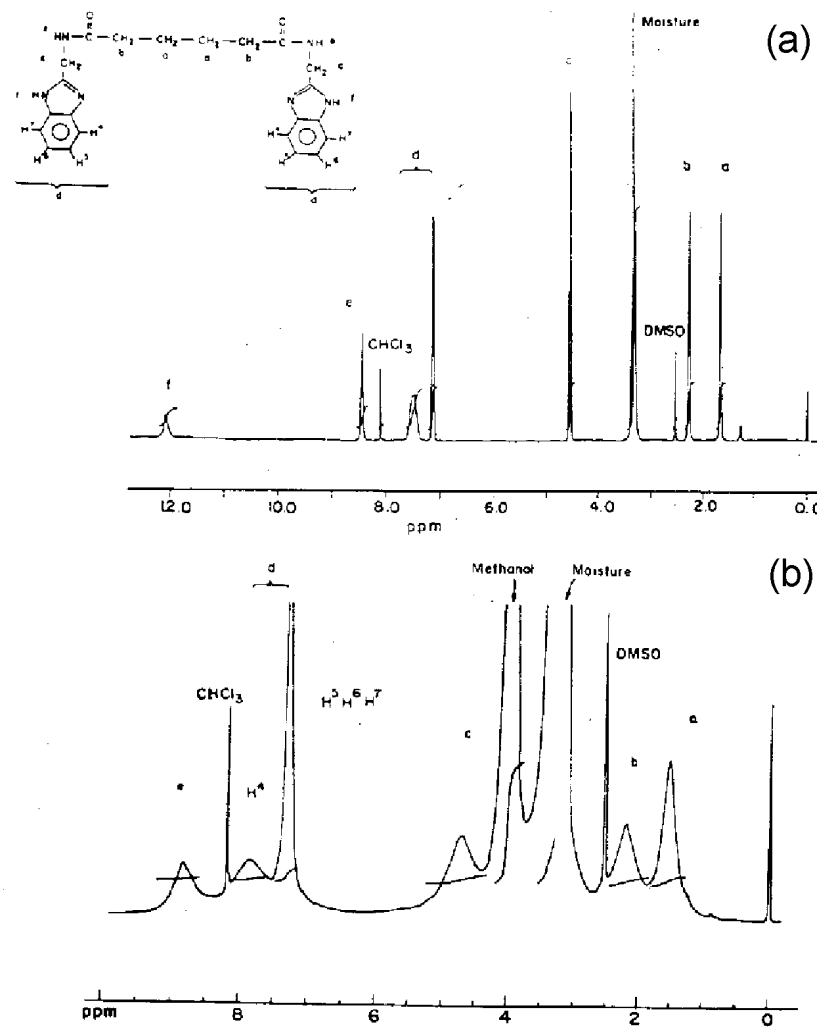

Figure 6. ${ }^{1} \mathrm{H}$ NMR (300 MHz) spectra of (a) GBHA and (b) $\mathrm{Cu}(\mathrm{GBHA}) \mathrm{NO}_{3}$ in $d_{6}$-DMSO. shifted compared to free ligand protons as they are in the vicinity of a Lewis acid $\mathrm{Cu}^{+}$and electronegative oxygen atoms of coordinated nitrate group which exert a deshielding effect through space electronic interaction. ${ }^{16}$ Broadening indicates that the protons are in a slightly paramagnetic surroundings which may be due to the presence of trace $\mathrm{Cu}$ (II) ions arising from a slight decomposition of $\mathrm{Cu}(\mathrm{I})$ complex.

All the GBHA-copper (II) complexes display a quasi reversible redox wave (figure 8) due to the copper(II)/Cu(I) process. Anodic shifts in $E_{1 / 2}$ values indicate the retention of the anion in the coordination sphere of $\mathrm{Cu}(\mathrm{II})$. The $E_{1 / 2}$ values vary anodically in the order $\mathrm{Cl}^{-}<\mathrm{NO}_{3}^{-}<\mathrm{SCN}^{-}$. This indicates that bound thiocyanate destabilizes the $\mathrm{Cu}$ (II) state while bound chloride stabilizes it. The $E_{1 / 2}$ value for the copper (I) complex $\left[\mathrm{Cu}^{1}\left(\mathrm{NO}_{3}\right)(\mathrm{GBHA})\right]$ was found to be $+0.622 \mathrm{~V}$ vs NHE. No redox wave associated with bound quinone or quinol was found in its cyclic voltammogram. When calculated against NHE, the $E_{1 / 2}$ values of the present series of $\mathrm{Cu}(\mathrm{II})$ complexes turn out to be quite positive as compared to those of other $\mathrm{Cu}(\mathrm{II})$ complexes with benzimidazole-based ligands $(+0.00$ to $+0 \cdot 446 \mathrm{~V})$ and some amide based complexes. Binding of amide N, preferably in depro-
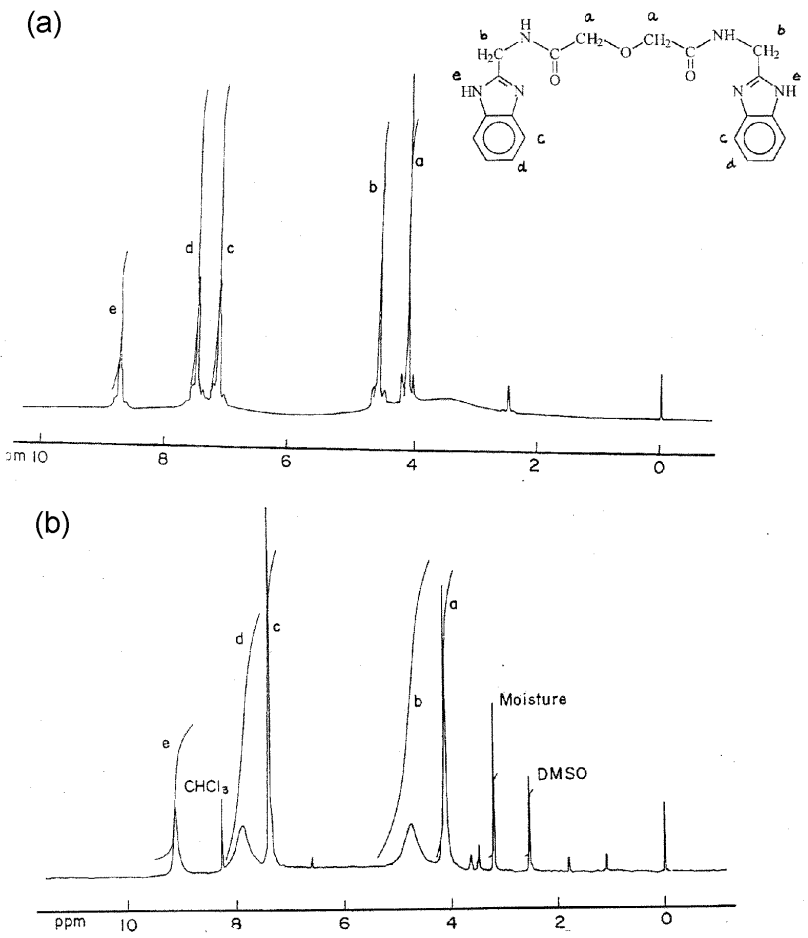

Figure 7. ${ }^{1} \mathrm{H}$ NMR spectra (in $d_{6}$-DMSO) of (a) GBOA, (b) $\left[\mathrm{Cu}(\mathrm{GBOA}) \mathrm{NO}_{3}\right]$. 

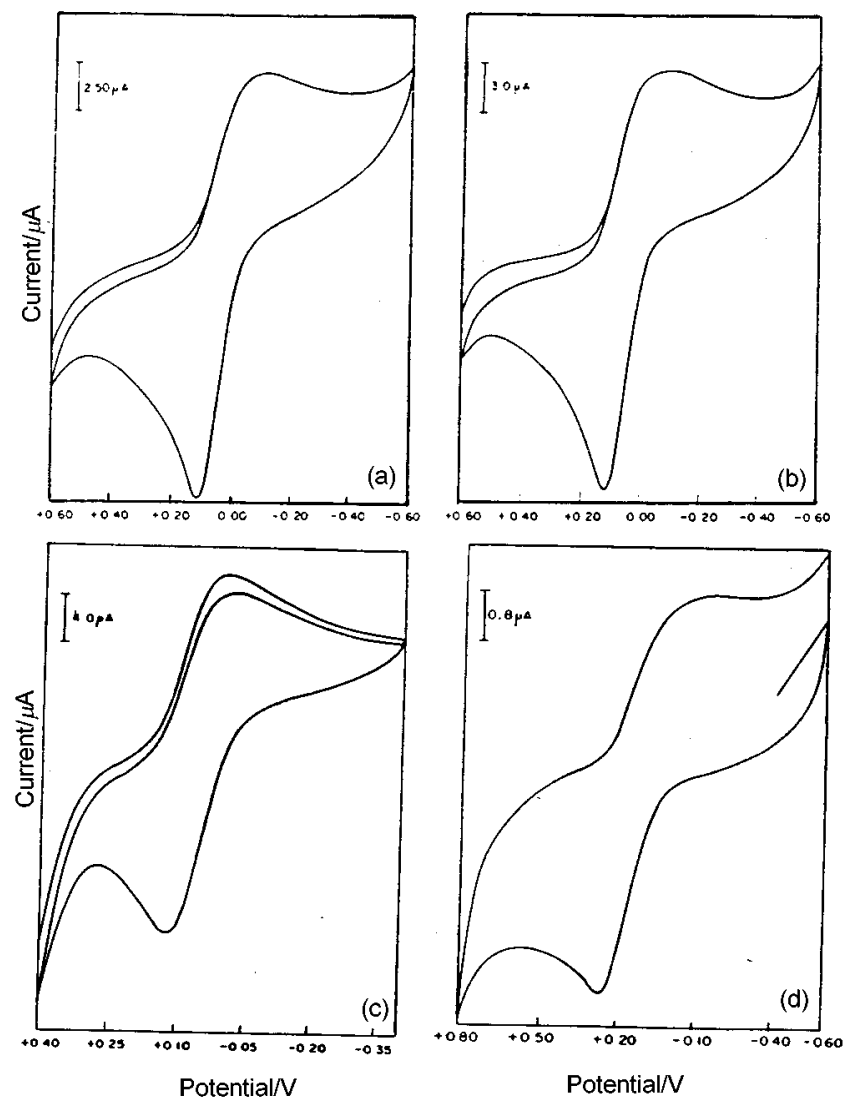

Figure 8. Cyclic voltammograms of (a) $\mathrm{Cu}(\mathrm{GBHA}) \mathrm{Cl}_{2}$, (b) $\mathrm{Cu}(\mathrm{GBHA})\left(\mathrm{NO}_{3}\right)_{2}$, (c) $\mathrm{Cu}(\mathrm{GBHA})(\mathrm{SCN})_{2}$ and (d) $\mathrm{Cu}(\mathrm{GBHA}) \mathrm{NO}_{3}$ in a $2: 8 \mathrm{DMSO}-\mathrm{CH}_{3} \mathrm{CN}$ solution at a scan rate of $100 \mathrm{Mv} / \mathrm{s}$.

tonated form, is known to stabilize copper in higher oxidation states $(+2,+3)$, thus cathodically shifting the reduction potential values. In contrast the binding of an amide carbonyl oxygen apparently has a destabilizing effect on $\mathrm{Cu}(\mathrm{II})$, leading to relatively a high anodic redox potential for this series of complexes.

For the GBOA-copper (II) complexes, a quasi reversible redox wave due to the copper (II)/Cu(I) redox couple in 2:8 DMSO: $\mathrm{CH}_{3} \mathrm{CN}$ mixed solvent system is observed. $E_{1 / 2}$ value of the complex $\left[\mathrm{CuCl}_{2}\right.$ $(\mathrm{GBOA})](+0.574 \mathrm{~V})$ is in the same range as for GBHA complex. Cyclic voltammograms of copper complexes of O-GBHA were recorded in dichloromethane solution containing $0.1 \mathrm{M}$ TBAP as supporting electrolyte at a glassy carbon working electrode. Ferrocene was used as internal standard, and potentials are referred to the ferrocenium/ferrocene $\left(\mathrm{Fc}^{+} / \mathrm{Fc}\right)$ couple. The cyclic voltammograms display a quasireversible wave at a fairly anodic potentials. This is attributed to the change of $\mathrm{Cu}$ (II) to $\mathrm{Cu}(\mathrm{I})$.

\section{Electron exchange reaction between $\left[\mathrm{Cu}\left(\mathrm{NO}_{3}\right)_{2}(\mathrm{GBHA})\right]$ and $o / p$-dihydroxybenzenes}

The reduction of $\left[\mathrm{Cu}\left(\mathrm{NO}_{3}\right)_{2}(\mathrm{GBHA})\right]$ by quinol was studied spectrophotometrically under anaerobic conditions. A $7.8 \mathrm{mM}\left[\mathrm{Cu}\left(\mathrm{NO}_{3}\right)_{2}(\mathrm{GBHA})\right]$ solution was prepared in a 1:9 DMSO: $\mathrm{CH}_{3} \mathrm{CN}$ solution. Dry nitrogen was bubbled through this septum-sealed solution for $30 \mathrm{~min}$. A spectrum of the above complex in this solvent system displays a broad band centred at $747 \mathrm{~nm}\left(\varepsilon=154 \mathrm{M}^{-1} \mathrm{~cm}^{-1}\right)$. A $35.5 \mathrm{mM}$ solution of quinol was prepared in a $1: 9 \mathrm{DMSO}: \mathrm{CH}_{3} \mathrm{CN}$ solution and dry nitrogen was bubbled through this septumsealed solution. A $0.04 \mathrm{ml}$ sample of the above quinol solution was added to $2.0 \mathrm{ml}$ of the $\mathrm{Cu}$ (II) complex solution in a septum-sealed quartz cuvette, with the help of an airtight syringe. The reduction of $\mathrm{Cu}$ (II) to $\mathrm{Cu}$ (I) was followed by observing the decrease in the optical density of the band centred at $747 \mathrm{~nm}$. The same volume of quinol was added periodically, and the decrease in band intensity was monitored till $747 \mathrm{~nm}$ band almost vanished (figure 9a). At this point the $\mathrm{Cu}$ : quinol stoichiometry was $1: 0.75$. The colour of the solution faded to light yellow, indicating the disappearance of the $\mathrm{Cu}(\mathrm{II})$ species in the solution. The above yellow solution could be reoxidised by atmospheric oxygen to give a green solution, restoring the wavelength maximum at $747 \mathrm{~nm}$. The same experiment was repeated with simple $\mathrm{Cu}\left(\mathrm{NO}_{3}\right)_{2}$ in the absence of the ligand GBHA. No fading of the light blue colour to yellow was observed. Instead the colour changed to green.

\section{Catechol oxidase studies}

A mixture of $2.0 \mathrm{ml}$ of catechol solution $(30 \mathrm{mM})$ in methanol (saturated with dry nitrogen) and $1.0 \mathrm{ml}$ of copper complex solution $(\sim 3 \mathrm{mM})$ in methanol (saturated with dry dioxygen) was placed in a $1 \mathrm{~cm}$ path length optical cell in a spectrometer. The final concentration of reaction mixture is catechol $(20 \mathrm{mM})$ and complex $(1 \mathrm{mM})$. The formation of $o$-benzouinone was followed by observing the increase of characteristic quinone absorption band in the range 390-410 nm (figure 9c). Blank run for catechol was also performed in the same manner by adding $1.0 \mathrm{ml}$ of oxygen saturated methanol to $2.0 \mathrm{ml}$ of catechol solution $(30 \mathrm{mM})$ in nitrogen saturated methanol. Similarly blank run for complex was also performed. The same experiment was repeated using 4methyl-catechol (4M Cat), 3,5-ditertiary-butylcatechol, 3,4-dihydroxybenzoic acid and dopamine(Dop). For 

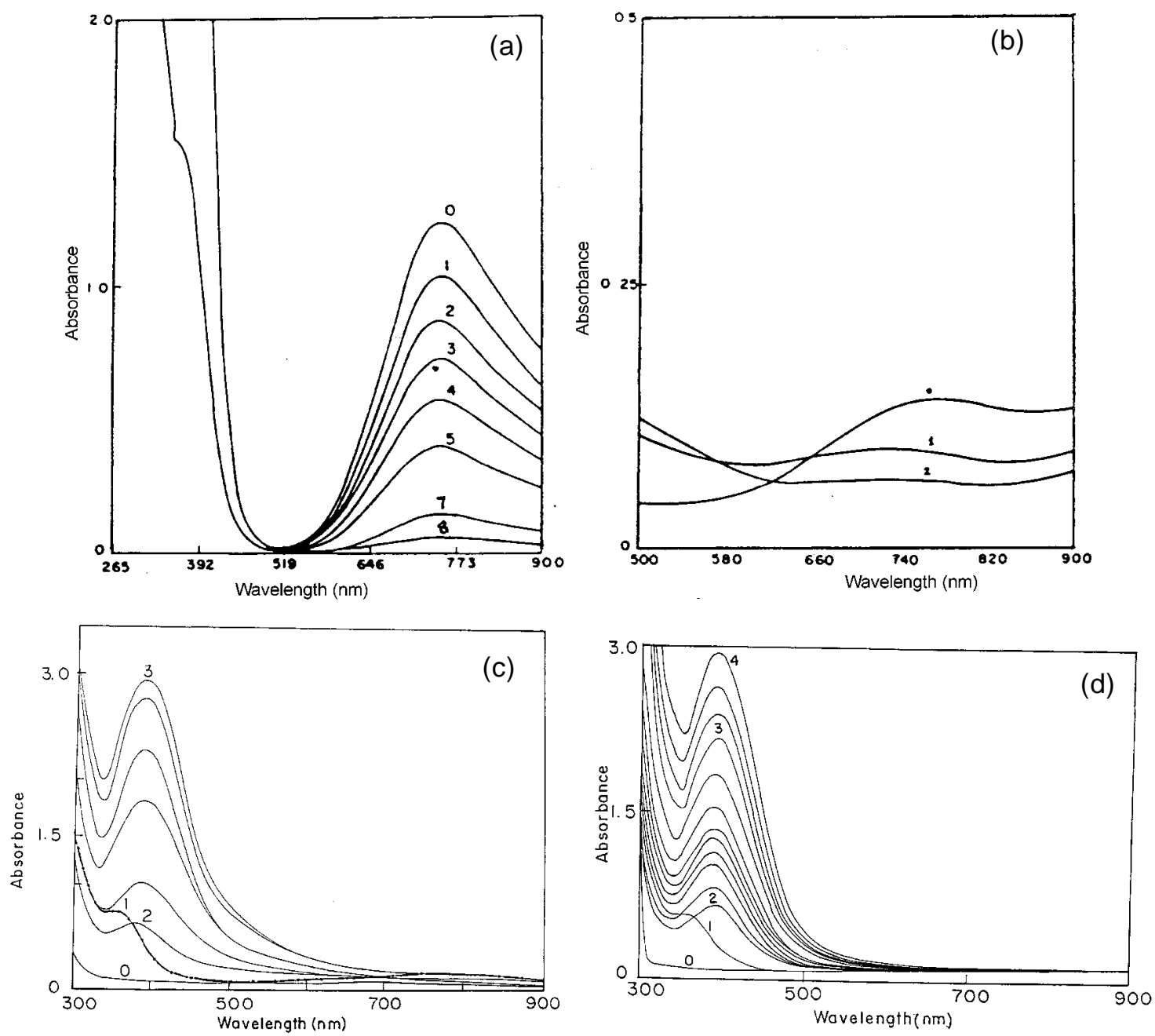

Figure 9. (a) Vis spectra of a $7.8 \mathrm{mM}$ solution of $\mathrm{Cu}(\mathrm{GBHA})\left(\mathrm{NO}_{3}\right)_{2}$ in a $2: 8 \mathrm{DMSO}-\mathrm{CH}_{3} \mathrm{CN}$ solution (curve 0 ) and $\mathrm{Cu}(\mathrm{GBHA})\left(\mathrm{NO}_{3}\right)_{2}$ in the presence of quinol (curve 1-8). (b) Visible spectra of a $\mathrm{Cu}(\mathrm{GBHA})\left(\mathrm{NO}_{3}\right)_{2}$ solution $(1 \cdot 1 \mathrm{mM}$, $\mathrm{MeOH})$ (curve 0) and $\mathrm{Cu}(\mathrm{GBHA})\left(\mathrm{NO}_{3}\right)_{2}$ in the presence of catechol (curves 1 and 2). (c) UV-Vis spectra of catechol solution $\left(20 \mathrm{mM}, \mathrm{N}_{2}\right.$ saturated methanol) [curve 0], new band generated in the presence of [Cu( $\left.\left.\mathrm{GBOA}\right) \mathrm{Cl}_{2}\right]$ solution ( $1 \mathrm{mM}, \mathrm{O}_{2}$ saturated methanol). Curve 2 - at $1 \mathrm{~min}$, curve 3 - at $40 \mathrm{~min}$. Curve 1 - charge transfer band of [Cu(GBOA) $\mathrm{Cl}_{2}$ ] in blank experiment. (d) UV-Vis spectra of 4-methylcatechol solution ( $20 \mathrm{mM}, \mathrm{N}_{2}$ saturated methanol) [curve 0], new band generated in the presence of $\left[\mathrm{Cu}(\mathrm{GBOA}) \mathrm{Cl}_{2}\right]$ solution $\left(1 \mathrm{mM}, \mathrm{O}_{2}\right.$ saturated methanol). Curve 2,2 min, curve 3 , 66 min. Curve 4, $110 \mathrm{~min}$, Curve 1, charge transfer band of [Cu(GBOA) $\mathrm{Cl}_{2}$ ] observed in blank experiment.

each set of observation, a curve of concentration of $o$-benzoquinone formed (calculated by using corresponding $\varepsilon$ values) versus time was plotted and initial rates were calculated by drawing a tangent to curve at $t=0$ and finding its slope. After this initial fast phase, the average rate of reaction was also calculated.

\subsection{Kinetic studies of the reaction of $\left[\mathrm{CuCl}_{2} \mathrm{GBOA}\right]$ with 3,5-ditertiarybutyl catechol}

The experiment described above was repeated with DTBC in two sets: (i) In the reaction mixture the concentration of catalyst $\left[\mathrm{CuCl}_{2}(\mathrm{GBOA})\right]$ was varied
$(0 \cdot 5,1 \cdot 0 \cdot 1,2 \cdot 0 \mathrm{mM})$ and concentration of DTBC was kept first at $20 \mathrm{mM}$. (ii) Concentration of DTBC was varied $(10,20,30,40 \mathrm{mM})$ and concentration of catalyst was kept fixed at $1 \mathrm{mM}$.

For each set of data initial rates were calculated and graphs of rate versus concentration of catechol were plotted.

For catechol, 4-methyl catechol and DTBC, the quinone production exceeds beyond the stoichiometric amount (table 1) while for dopamine, the o-benzouinone formed decayed very rapidly probably undergoing further reaction. With 3,4-DHB, no quinone generation could be observed, however the absorption in the region 390-410 $\mathrm{nm}$ increased continuously 
Table 1. Rates of reaction observed with various substrates and $\left[\mathrm{CuCl}_{2}(\mathrm{GBOA})\right]$ as catalyst

\begin{tabular}{|c|c|c|c|c|c|c|}
\hline Substrate & $\begin{array}{c}\lambda_{\max }(\mathrm{nm}) \\
\text { product } \\
\text { o-enzoquinone }\end{array}$ & $\begin{array}{c}\text { Initial } \\
\text { rate } \\
\left(\mathrm{M} \mathrm{min}^{-1}\right)\end{array}$ & $\begin{array}{l}\text { Average } \\
\text { rate } \\
\left(\mathrm{M} \mathrm{min}^{-1}\right)\end{array}$ & $\begin{array}{l}\text { Concentration } \\
\text { of product } \\
\text { formed at } 35 \mathrm{~min} \\
\qquad(\mathrm{mM})\end{array}$ & $\begin{array}{l}\text { Minimum conver- } \\
\text { sion (mM) before } \\
\text { decomposition } \\
\text { of product }\end{array}$ & $\begin{array}{l}\text { Catalyst } \\
\text { turnover }\end{array}$ \\
\hline Catechol & 392 & $1.33 \times 10^{-4}$ & $2.6 \times 10^{-5}$ & $1 \cdot 1114$ & $1.4(7 \%)$ & 3 \\
\hline 4-Methyl catechol & 392 & $2.10 \times 10^{-4}$ & $9.3 \times 10^{-4}$ & 0.722 & $2 \cdot 4(12 \%)$ & 5 \\
\hline 3,5-Ditertiarybutylcatechol & 399 & $3 \cdot 12 \times 10^{-4}$ & $2.25 \times 10^{-5}$ & 1.732 & $16 \cdot 8(84 \%)$ & 34 \\
\hline Dopamine & 380 & $\begin{array}{l}\text { Band decayed } \\
\text { within } 10 \mathrm{~min}\end{array}$ & & & & \\
\hline 2,4-Dihydroxybenzoic acid & & $\begin{array}{l}\text { Very week } \\
\text { loulder decayed } \\
\text { within } 5 \text { min }\end{array}$ & & & & \\
\hline
\end{tabular}

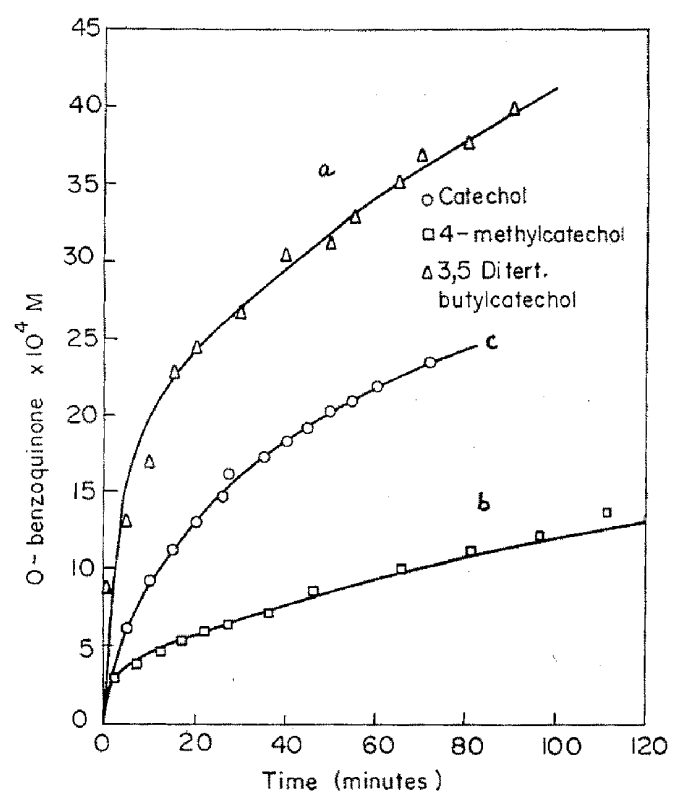

Figure 10. Plot of $o$-benzoquinone (M), vs time for various catechols (20 mM); (a) 3,5-di-t-butylcatechol; (b) 4-methylcatechol; (c) catechol at $\left[\mathrm{CuCl}_{2}(\mathrm{GBOA})\right]=1 \mathrm{mM}$.

without displaying any well defined band indicating the occurrence of multiple reactions.

For catechol, DTBC, 4M cat, DOP and 3,4DHB, the concentration of corresponding quinone produced was calculated using $\varepsilon=1585 \mathrm{M}^{-1} \mathrm{~cm}^{-1}, 1500^{17 a} 2140$ and $2455 \mathrm{M}^{-1} \mathrm{~cm}^{-1}$, ${ }^{17 \mathrm{~b}}$ respectively. For all these, quinone produced versus time curve follows biphasic behaviour (figure 10). The reaction occurs with a fast phase followed by a slower reaction, for both phases, the reaction rates have been calculated. Initial rates have been calculated by drawing a tangent to the curve at $t=0$. For $o$-diphenol initial concentration is $20 \mathrm{mM}$ and for $\left[\mathrm{CuCl}_{2} \mathrm{GBOA}\right]$ initial concentration is $1 \mathrm{mM}$, the initial rates were found to be $1.33 \times 10^{-4}$, $2.1 \times 10^{-4}$ and $3.1 \times 10^{-4} \mathrm{M} \mathrm{min}^{-1}$ for cat, $4 \mathrm{M} \mathrm{Cat}$ and DTBC respectively. For DTBC the conversion to DTBQ was $84.5 \%$ complete, i.e. turnover of 34 times was found within $27 \mathrm{~h}$. During this time period, ae- rial oxidation of DTBC contributed to only $0.5 \%$ of the product DTBQ (confirmed by performing blank). Table 1 gives the conversion of various catechols to quinones at $30 \mathrm{~min}$. The rates, though not comparable to the copper enzyme, tyrosinase, are found to be much higher than other synthetic complexes. ${ }^{17 \mathrm{c}}$ The activity is found to vary with the substituent on catechol as HOOC $<\mathrm{CH}_{2} \mathrm{CH}_{2} \mathrm{NH}_{2}<\mathrm{H}<\mathrm{CH}_{3}<t$-Bu. The order of reactivity shows that the o-diphenol where the substituent is the best electron-donating group gives the highest activity. Similar trends are found by other groups ${ }^{17 b}$ also both for synthetic complexes and the enzyme tyrosinase. These results are consistent with the catecholase activity, which is dependent upon the formation of a Lewis acid-base bond between copper (II) and a $o$-diphenol oxygen atom. Based on this, absence of any quinine formation for 3,4-DHB could be understood in terms of a greater electron withdrawing effect of the carboxyl moiety, i.e. the $\mathrm{COOH}$ group in this particular catechol.

Kinetic studies have also been carried out using the substrate DTBC and the catalyst $\left[\mathrm{CuCl}_{2}(\mathrm{GBOA})\right]$. For DTBC oxidation, the initial rate was found to depend linearly on the catalyst concentration while it is found to be dependent on the square root of the concentration of DTBC itself. It has been reported earlier that for a single mono-nuclear complex, the rate of DTBC oxidation depends linearly on the square of the copper (II) concentration, while our results indicate that it depends only on the first power of catalyst concentration. This implies that in the present series of complexes, the possibility of catechol bridging the two copper (II) centres is remote. This is quite likely due to the rigidity of bulky benzimidazole groups that may hinder the formation of such bridged species with catechol. Thus, the ratedetermining step involves only a single metal centre. Such an observation is not uncommon. This study mimics the activity of copper containing mettyrosinase and catechol oxidase enzymes. 


\section{Oxidation of 2,4,6-tri-t-butylphenol (TTBP)}

Spectrophotometric analysis, of the reaction mixture consisting of TTBP and $\left[\mathrm{Cu}\left(\mathrm{NO}_{3}\right)(\mathrm{GBHA})\right]\left(\mathrm{NO}_{3}\right)$ in the ratio $1: 22$ in $\mathrm{MeOH}$ saturated with dioxygen was carried out in the range 200-1100 nm (figure 11). A solution of pure TTBP in $\mathrm{MeOH}$ displays a weak band at $420 \mathrm{~nm}(\log \varepsilon=0.477)$ with a shoulder at $400 \mathrm{~nm}$. On mixing TTBP with $\left[\mathrm{Cu}\left(\mathrm{NO}_{3}\right)(\mathrm{GBHA})\right]$ $\left(\mathrm{NO}_{3}\right)$ an instant growth in bands at 400 and $420 \mathrm{~nm}$ is observed along with a new band at $318 \mathrm{~nm}$, observed in a dilute reaction mixture. The generation of new bands at 318 and $400 \mathrm{~nm}$ indicated the formation of new products in the reaction mixture. The character of the original $400 \mathrm{~nm}$ shoulder also changes which starts to acquire the shape of a proper band with time. The band at $420 \mathrm{~nm}$ gradually loses its wellresolved shape to a shoulder with a shift in $\lambda_{\max }$ to $416 \mathrm{~nm}$. The $d-d$ band of $\left[\mathrm{Cu}\left(\mathrm{NO}_{3}\right)(\mathrm{GBHA})\right]\left(\mathrm{NO}_{3}\right)$ (780 nm, $\log \varepsilon=1.92)$ in methanol shows an initial increase in intensity soon followed by a slight drop accompanied by a shift in $\lambda_{\max }$ to $770 \mathrm{~nm}$ (figure 12). This indicates the formation of active $\mathrm{Cu}$ (II) species.

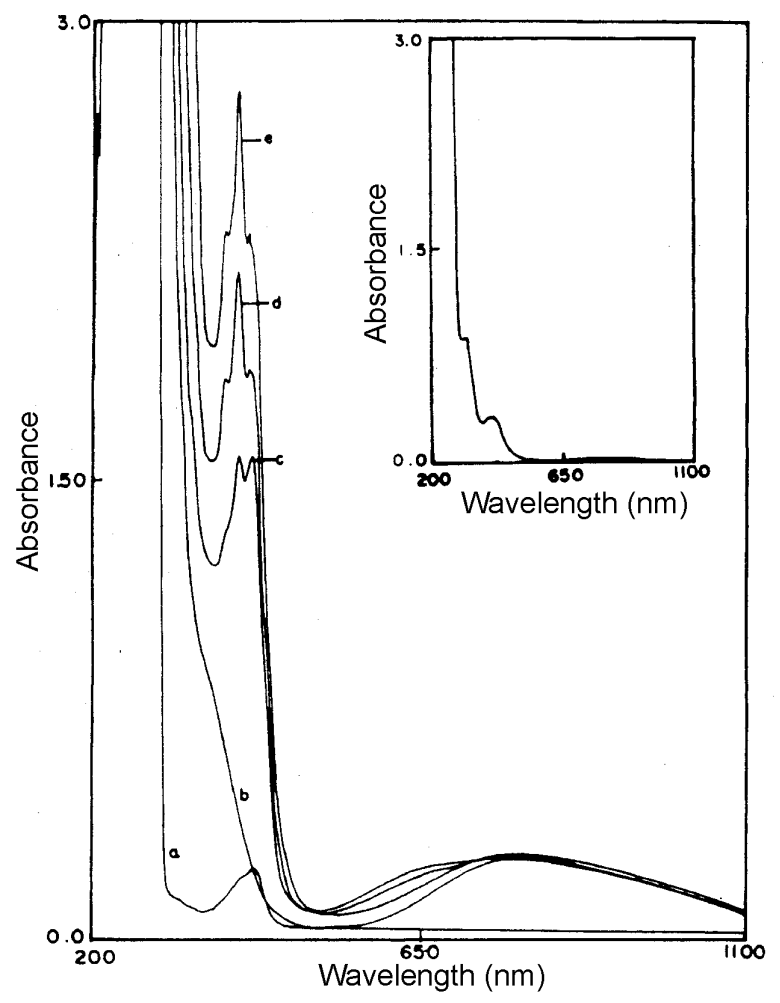

Figure 11. UV-Vis spectra of (a) $\mathrm{O}_{2}$ saturated methanolic solution $(3 \cdot 2 \mathrm{mM})$ of $\left[\mathrm{Cu}\left(\mathrm{NO}_{3}\right)(\mathrm{GBHA})\right]\left(\mathrm{NO}_{3}\right)(\mathrm{b}) \mathrm{O}_{2}$ saturated methanolic solution $(65 \mathrm{mM})$ of TTBP (c)-(e) reaction mixture at 1,15 and 30 min respectively after mixing of reactants. Inset. Diluted reaction mixture showing the band at $318 \mathrm{~nm}$.

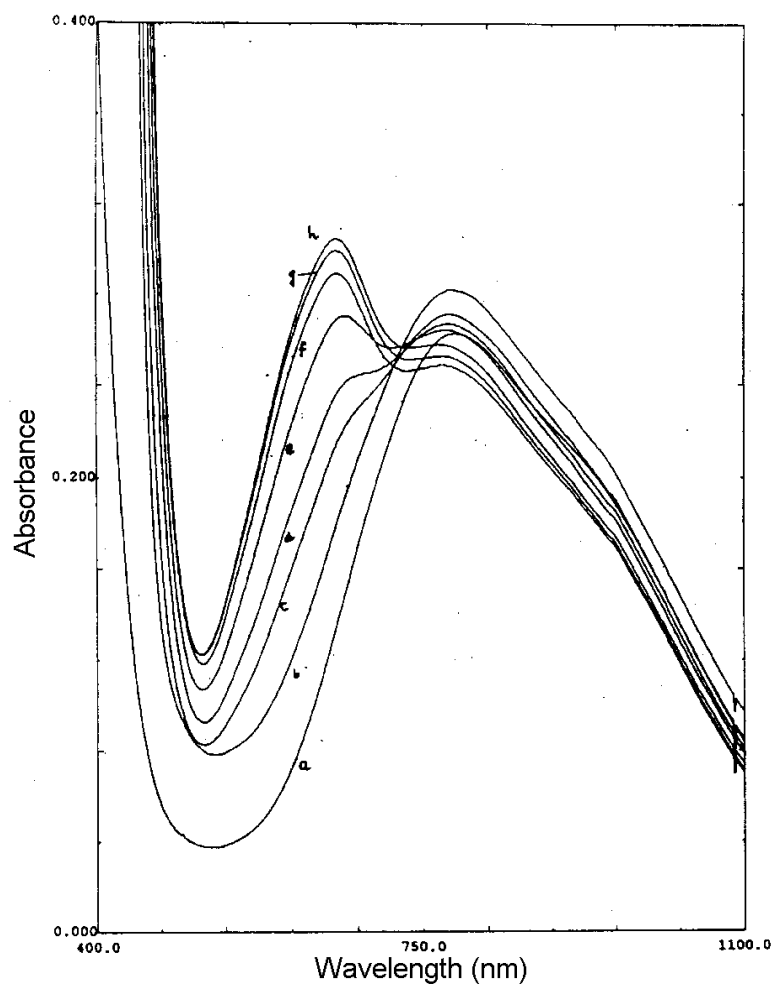

Figure 12. Visible spectra ( $d-d$ band) of (a) $\left[\mathrm{Cu}\left(\mathrm{NO}_{3}\right)\right.$ $(\mathrm{GBHA})]\left(\mathrm{NO}_{3}\right)(3.2 \mathrm{mM})$ in methanol. Reaction mixture containing catalyst $(3.2 \mathrm{mM})$ and TTBP $(65 \mathrm{mM})$ in $\mathrm{O}_{2}$ saturated methanol at (a) 1 (b) 15 (c) 30 (d) 45 (e) 70 (f) 90 and $(\mathrm{g}) 120 \mathrm{~min}$.

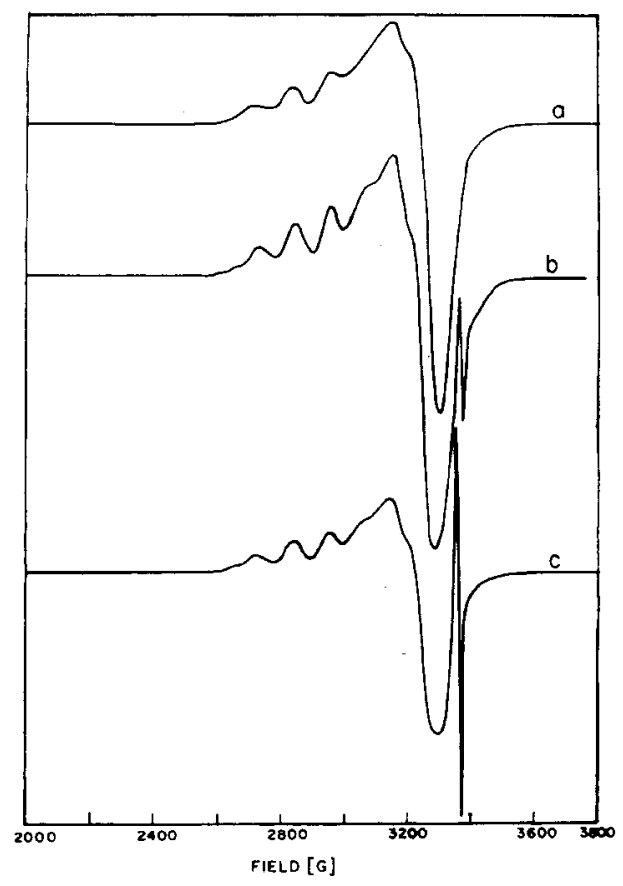

Figure 13. $\mathrm{X}$-band EPR spectra of (a) $\left[\mathrm{Cu}\left(\mathrm{NO}_{3}\right)\right.$ (GBHA)] $\left(\mathrm{NO}_{3}\right)$ in methanol, (b) reaction mixture at $1 \mathrm{~min}$ (c) $30 \mathrm{~min}$ at microwave frequency $9.4 \mathrm{GHz}$ and receiver gain $10^{3}$. 
A new band is also generated at $664 \mathrm{~nm}$, which grows in intensity for about $70 \mathrm{~min}$ after which it starts to decay ( $\lambda_{\max }$ shifting to $657 \mathrm{~nm}$ ). The yellow colour of the reaction mixture turns green within this time period. This new band generated was assigned to tri-t-butylphenoxyl radical. ${ }^{18}$ The radical generation was also confirmed by low temperature $(120 \mathrm{~K}) \mathrm{EPR}$ measurements of the reaction mixture (figure 13). Pure $\left[\mathrm{Cu}\left(\mathrm{NO}_{3}\right)(\mathrm{GBHA})\right]\left(\mathrm{NO}_{3}\right)$ in $\mathrm{MeOH}$ at $120 \mathrm{~K}$ displays a four-line EPR signal in the $g_{\|}$region and an unresolved signal in the $g_{\perp}$ region with $g_{\|}=2.40$ and $A_{\|}=123 \mathrm{G}, g_{\perp}=2.093$. As soon as TTBP is added to the $\mathrm{Cu}$ (II) complex solution, a new signal is observed at field strength $\mathrm{H}=3366.5 \mathrm{~Hz}$ and $g=2.004$, this indicated the presence of free radicals in the reaction mixture. The signal grows with time, with a simultaneous drop in $\mathrm{Cu}$ (II) complex signal intensity. Thus both spectrophotometric and EPR measurements confirm the involvement of tri-t-butylphenoxyl radical in TTBP oxidation reaction.

\section{Isolation of reaction products}

Both the major products (A) 2,6-di-t-butyl-1,4benzoquinone and (B) 2,4-di-t-butyl-1,6-benzoquinone were isolated by column chromatography. A has $R_{f}=0.73$ and B has $R_{f}=0.3$ in benzene. They further purified through preparative TLC in yields $22 \%$ (A) and $8.6 \%$ (B). IR spectra (in $\mathrm{KBr}$ ) of both the products display two new bands in the range $1600-1700 \mathrm{~cm}^{-1}$ confirming the presence of carbonyl group in them. Product A has strong bands at 1656 and $1598 \mathrm{~cm}^{-1}$ indicating two different types of carbonyls in the molecule. Product B displays two bands at 1656 and $1620 \mathrm{~cm}^{-1}$, again due to two different types of carbonyls. This observation supports the benzoquinone type of structures for A and B.

${ }^{1} \mathrm{H}-\mathrm{NMR}$ spectrum of the product $\mathrm{A}$ in $d_{6}$-DMSO displays signals at $\delta(\mathrm{ppm}) 1 \cdot 24\left(\mathrm{~s}, 18 \mathrm{H}_{\mathrm{a}}\right), 6 \cdot 51(\mathrm{~s}, 2$ $\mathrm{H}_{\mathrm{b}}$ ). This observation supports $p$-benzoquinone structure: ${ }^{13} \mathrm{C}$-NMR of $\mathrm{A}$ in $d_{6}$-DMSO give signals at $\delta$ (ppm) 189.4 (C-4), 188.2 (C-1), 158.3 (C-2, C-6), 142 (C-3, C-5), 35.2 (C-7), $29 \cdot 7$ (C-8). In mass spectrum, the base peak at $m / e 220$ also supports the above structure. Other peaks observed are at $\mathrm{m} / \mathrm{e}$ 191, 179, 165, 149 and 107.

${ }^{1} \mathrm{H}-\mathrm{NMR}$ spectrum of the product $\mathrm{B}$ in $d_{6}$-DMSO displays signals at $\delta(\mathrm{ppm}) 1 \cdot 19\left(\mathrm{~s}, 9 \mathrm{H}_{\mathrm{a}}\right), 1 \cdot 22(s$, $\left.9 \mathrm{H}_{\mathrm{b}}\right), 6 \cdot 14\left(d, 1 \mathrm{H}_{\mathrm{c}}\right), 6 \cdot 97\left(d, 1 \mathrm{H}_{\mathrm{d}}\right)$. The two aromatic protons are meta coupled, coupling constant $\mathrm{J}$ being $2 \cdot 1 \mathrm{~Hz}$. The presence of two different types of $t$-butyl groups supports $o$-benzoquinone structure: ${ }^{13} \mathrm{C}$ NMR of B in $d_{6}$-DMSO give signals at $\delta(\mathrm{ppm}) 180$ (C-1, C-2), $162 \cdot 5$ (C-4), 148.9 (C-6), 133.4 (C-3), 124 (C-5), $35 \cdot 7$ (C-7), 35.0 (C-9), $29 \cdot 0$ (C-10), $27 \cdot 5$ (C-10). In mass spectrum, the base peak at $m / e 220$ is observed.

Product A shows three bands in UV-Vis region $450 \mathrm{~nm}(\log \varepsilon=1 \cdot 59), 318 \mathrm{~nm}(\log \varepsilon=2 \cdot 76), 255 \mathrm{~nm}$ $(\log \varepsilon=4.57)$ while product $\mathrm{B}$ shows bands at $537 \mathrm{~nm}(\log \varepsilon=1 \cdot 68), 400 \mathrm{~nm}(\log \varepsilon=2.93), 255 \mathrm{~nm}$ $(\log \varepsilon=3 \cdot 65)$. The shift of band maximum towards longer wavelengths in B as compared to A confirms extended conjugation in $\mathrm{B}$.

\section{Mechanism of TTBP oxidation}

The catalyst $\left[\mathrm{Cu}\left(\mathrm{NO}_{3}\right)(\mathrm{GBHA})\right]\left(\mathrm{NO}_{3}\right)$ has copper in +II oxidation state and is in a square-pyramidal coordination environment. The first step possibly involves the deprotonation of TTBP whereby the TTBP anion coordinates to $\mathrm{Cu}$ (II). The $\mathrm{Cu}$ (II) complex is capable of oxidizing TTBP to TTBP radical simultaneously producing the reduced catalyst, i.e. $\mathrm{Cu}(\mathrm{I})$ species. The appearance of a band at $664 \mathrm{~nm}$ and the appearance of a sharp EPR signal at $g=2.004$ confirms the formation of the phenolate radical. The reduced catalyst $\mathrm{Cu}(\mathrm{I})$ is then reoxidised by molecular oxygen to give the superoxide radical (scheme 1).

The super oxide anion radical generated then attacks at the para position of rearranged TTBP radical to produce an intermediate hydroperoxy compound which rapidly eliminates a molecule of $t-\mathrm{BuOH}$ to give product $\mathrm{A}$. In yet another competitive reaction,

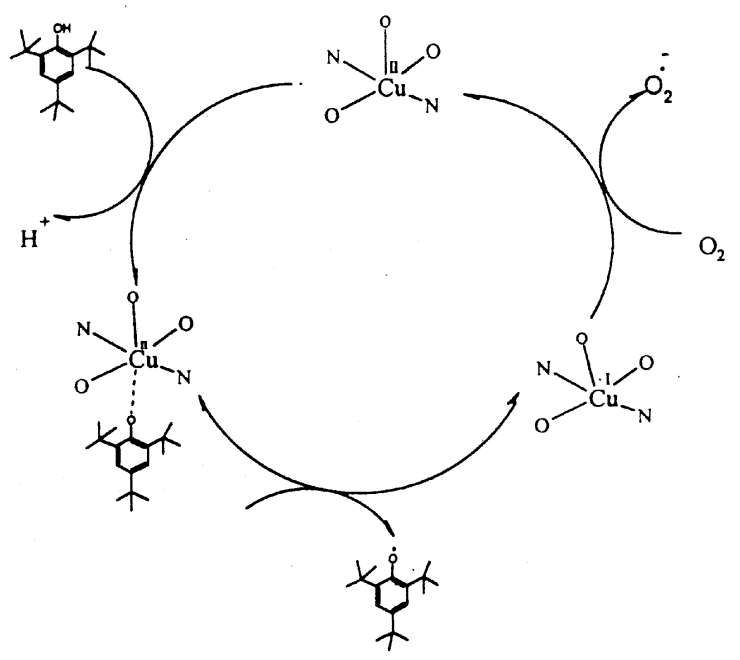

Scheme 1. Catalytic generation of TTBP radical by $\left[\mathrm{Cu}\left(\mathrm{NO}_{3}\right)(\mathrm{GBHA})\right]\left(\mathrm{NO}_{3}\right)$. 


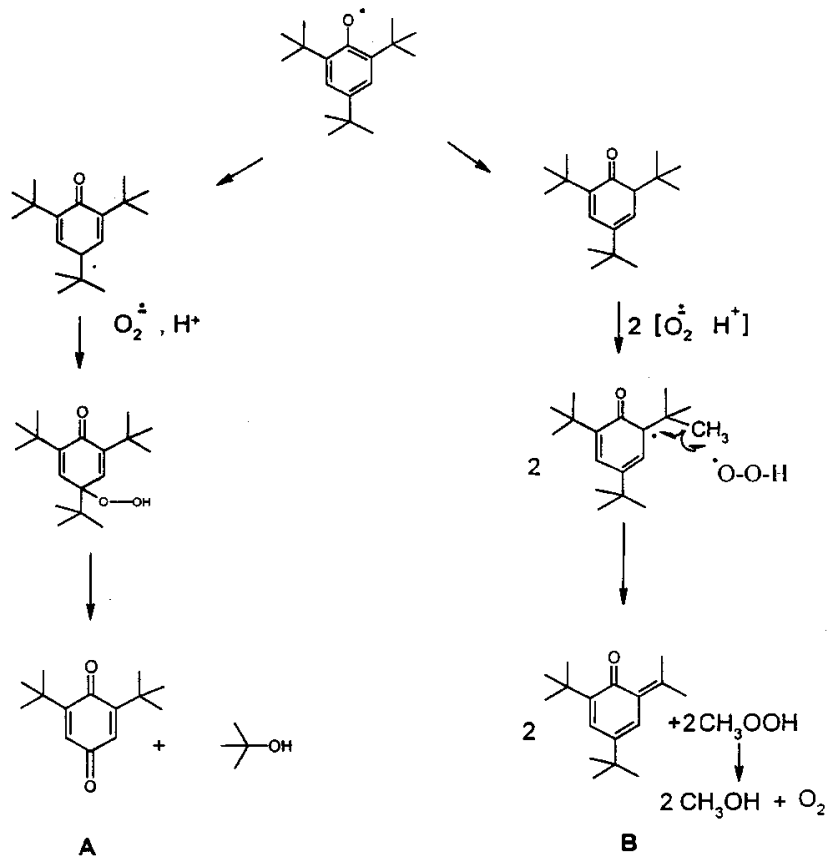

Figure 14. Mechanism of TTBP oxidation.

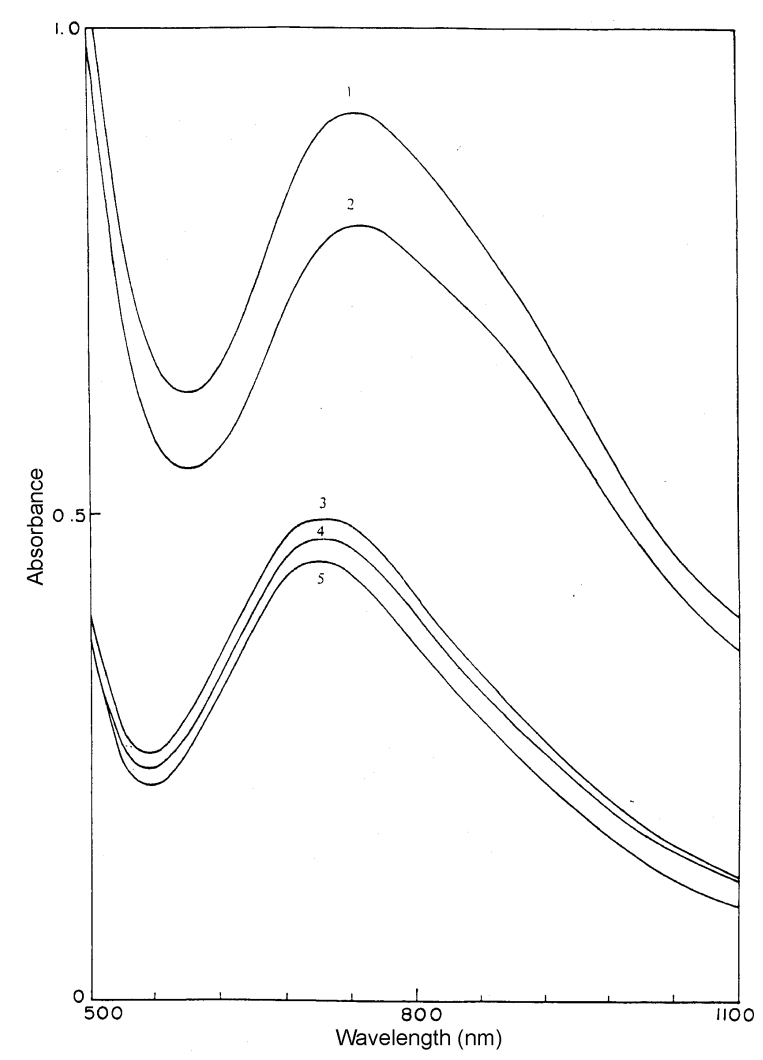

Figure 15. Curve $1, d-d$ band spectrum of a reaction mixture $(0.0308 \mathrm{mmol}$ of $\mathrm{CuCl}(\mathrm{O}-\mathrm{GBHA})] \mathrm{Cl}, 0 \cdot 616 \mathrm{mmol}$ of 4-chlorobenzyl alcohol, $0.616 \mathrm{mmol}$ of cumenyl hydroperoxide) at the time of mixing. Curves $2-4, d-d$ band spectra of a reaction mixture after every $10 \mathrm{~min}$ of heating curve $5, d-d$ band spectrum of a reaction mixture $1 \mathrm{~h}$ after the initiation of reaction. the TTBP radical undergoes rearrangement to produce an unpaired electron at the ortho position which undergoes attack by TTBP radical in the same manner to give product $\mathrm{B}$. The present study thus indicates that the complex $\left[\mathrm{Cu}\left(\mathrm{NO}_{3}\right)(\mathrm{GBHA})\right]\left(\mathrm{NO}_{3}\right)$ is able to carry out oxidative hydroxylation with simultaneous dealkylation reaction in organic substrates and is an example of activation of molecular oxygen (figure 14).

\section{Oxidation of alcohols}

A $25 \mathrm{ml}$, two-necked flask was fitted with a reflux condenser and an oxygen/nitrogen inlet. Copper complex [CuCl(O-GBHA)]Cl (23.5 mg; $0.0308 \mathrm{mmol})$ and chlorobenzyl alcohol $(87.83 \mathrm{mg} ; 0.616 \mathrm{mmol})$ in $10 \mathrm{ml} \mathrm{CH}_{2} \mathrm{Cl}_{2}$ were stirred at room temperature for $10 \mathrm{~min}$ under nitrogen. Cumenyl hydroperoxide $(0.088 \mathrm{ml} ; 0.616 \mathrm{mmol})$ was added and stirred for 20 min. At this point the $d-d$ band of the copper complex was monitored (figure 15). This was followed by raising the temperature of the reaction mixture to $40-45^{\circ} \mathrm{C}$ on a water bath. Stirring was continued for 1-2 $\mathrm{h}$. The reaction was monitored by visible spectroscopy, and it was found that the $d-d$ band intensity drops to $50 \%$ of its original value, within a $30 \mathrm{~min}$ period (figure 15), and subsequently remains constant for the remaining period of the reaction. No new band is generated during the reaction cycle in the region 300-1100 $\mathrm{nm}$. The reaction mixture was further stirred for another $24 \mathrm{~h}$ at room temperature. TLC of the reaction mixture showed two major products that were visualized by spraying an ethanolic solution of 2,4-DNP. The reaction products were finally separated by column chromatography using $10 \%$ ethylacetate/hexane as eluent (one of them was identified as the corresponding aldehyde and the other as acetophenone). Products separated by column chromatography were quantitatively estimated using HPLC. A standard curve for each of the aldehydes was generated, and the concentration of the unknown aldehyde was obtained with reference to the standard curve. On this basis, the percentage conversion and turnover numbers are reported in table 2.

Identity of the aldehydes and acetophenone formed was confirmed by ${ }^{1} \mathrm{H}-\mathrm{NMR}$ of their respective DNP derivatives and are in confirmation with those reported in the literature. No products were obtained if the solution was not warmed to $40-45^{\circ} \mathrm{C}$ for $30 \mathrm{~min}$, and the oxidation state of $\mathrm{Cu}(\mathrm{II})$ also does not change if the reaction mixture is not heated as above; this is confirmed by observing minimal change in $d-d$ band 
Table 2. Percentage yield of products obtained on oxidation of various alcohols using $[\mathrm{CuCl}(\mathrm{O}-\mathrm{GBHA})] \mathrm{Cl}$ as catalyst.

\begin{tabular}{lcc}
\hline \multirow{2}{*}{ Substrate } & \multicolumn{2}{c}{ Catalyst $-\left[\mathrm{Cu}(\mathrm{OctGBHA}) \mathrm{Cl}_{2}\right]$} \\
\cline { 2 - 3 } & ArCHO $(\%$ yield $)(\mathrm{TON})$ & $\mathrm{PhCOCH}_{3}(\%$ yield $)(\mathrm{TON})$ \\
\hline Benzyl alcohol & $38 \cdot 96[16]$ & $27 \cdot 8[16]$ \\
4-Chlorobenzyl alcohol & $43 \cdot 3[18]$ & $42 \cdot 3[23]$ \\
4-Ethylbenzyl alcohol & $51 \cdot 93[18]$ & $47 \cdot 1[26]$ \\
4-Methylbenzyl alcohol & $64 \cdot 94[27]$ & $27 \cdot 8[16]$ \\
4-Nitrobenzyl alcohol & $32 \cdot 5[13]$ & $27 \cdot 8[16]$ \\
1-Phenylethanol & - & $65 \cdot 70[32]$ \\
\hline
\end{tabular}

TON = turnover number

intensity for such room temperature solutions, for a period of several hours. Similar results were obtained using $\left[\mathrm{Cu}\left(\mathrm{NO}_{3}\right)(\mathrm{O}-\mathrm{GBHA})\right]\left(\mathrm{NO}_{3}\right)$ as catalyst.

It is well established that in the absence of protic solvent, the hydroperoxides are likely to cleave by homolysis reaction. ${ }^{19}$ Further it has been reported that cumenyl hydroperoxide generates a cumylperoxyl radical $\left(\mathrm{R}_{3} \mathrm{COO}{ }^{\circ}\right)$ with metal ion complexes with concomitant change in oxidation state of the metal ion. ${ }^{20}$ It is also established that cumylperoxyl radicals decompose by a mechanism which finally generates acetophenone as one of the products. ${ }^{21}$ The above two reaction sequences are presented as:

$$
\begin{aligned}
& \mathrm{R}_{3} \mathrm{COOH}+\mathrm{Cu}(\mathrm{II}) \rightarrow \mathrm{R}_{3} \mathrm{COO}^{\bullet}+\mathrm{Cu}(\mathrm{I})+\mathrm{H}^{+}, \\
& \mathrm{R}_{3} \mathrm{COOH}+\mathrm{Cu}(\mathrm{I}) \rightarrow\left[\mathrm{R}_{3} \mathrm{CO} \ldots \mathrm{Cu}(\mathrm{II})\right]+\mathrm{OH}^{-}, \\
& \mathrm{R}_{3} \mathrm{COO}^{\bullet} \rightarrow \mathrm{R}_{3} \mathrm{CO}^{\bullet}+1 / 2 \mathrm{O}_{2}, \\
& \mathrm{R}_{3} \mathrm{CO}^{\bullet} \rightarrow \mathrm{PhCOCH}_{3}+\mathrm{R}^{\bullet} .
\end{aligned}
$$

It is assumed that the above reaction sequences are dominantly active in the present catalytic oxidation of alcohol. A spectral monitoring of the course of catalytic reaction shows a drop in $d-d$ band intensity to almost half of its original value after thermally activating the reaction for nearly $30 \mathrm{~min}$. This may imply the reduction of copper (II) to copper (I). However, there appears to be some structural change which takes place during the activation; the $d-d$ band shifts by almost $30 \mathrm{~nm}\left(\lambda_{\max }: 712 \mathrm{~nm}\right)$ to shorter wavelengths and a weak shoulder around $880 \mathrm{~nm}$ is also lost, when $[\mathrm{CuCl}(\mathrm{O}-\mathrm{GBHA})] \mathrm{Cl}$ complex is used as a catalyst. This possibly implies a loss of the axially bound atom in the complex leading to formation of an "active copper species". ${ }^{22}$

In an attempt to identify the $\mathrm{Cu}$ (II) species that may be active in the peroxide-dependent oxidation of aryl alcohols, a sample of $\mathrm{Cu}$ (II) species (which is formed after the reaction is thermally activated for $30 \mathrm{~min}$ in the presence of substrate and cumenyl hydroperoxide) was isolated and EPR of this sample was taken in $\mathrm{CH}_{2} \mathrm{Cl}_{2}$ at liquid nitrogen temperature. For comparison, the EPR of the original complex $[\mathrm{CuCl}(\mathrm{O}-\mathrm{GBHA})] \mathrm{Cl}$ was utilized in this reaction, as a catalyst was also taken in the same solvent and at liquid nitrogen temperature. A comparison of the EPR spectra of the two species indicates that there is slight variation in their respective $g$-values; however, they follow the order $g_{\|}>g_{\perp}>2.0023$, implying a $d_{x^{2}-y^{2}}$ ground state. There are, however, changes in the hyperfine coupling constants ([CuCl(O-GBHA) $] \mathrm{Cl})$ prior to reaction, $g_{\|}=2 \cdot 40, g_{\perp}=2 \cdot 12$, and $A_{\|}=120 \mathrm{G}$; ([CuCl$(\mathrm{O}-\mathrm{GBHA})] \mathrm{Cl})$ after the reaction, $g_{\|}=2 \cdot 34$, $g_{\perp}=2 \cdot 09$, and $\left.A_{\|}=135 \mathrm{G}\right)$. The $g_{\|} / 10^{-4} A_{\|}$index is 200 for the original complex while it is 173 for the active species. This implies that the active species is more planar relative to the starting complex..$^{23}$ This relative planarity may result due to the relieving of strain in the complex caused by the loss of the axially bound atom in the "active-copper species".

The role of molecular oxygen was also studied by allowing a slow stream of $\mathrm{O}_{2}$ during the oxidation reaction catalysed by the $[\mathrm{CuCl}(\mathrm{O}-\mathrm{GBHA})] \mathrm{Cl}$ complex. The change observed in the $d-d$ band of the catalyst is depicted in figure 16a. It is found that the activecopper species with a $\lambda_{\max } \sim 712 \mathrm{~nm}$ is again generated, but in this case there is no drop in the absorbance of the $d-d$ band of the catalyst; rather, there is slight increase in the absorbance. This implies a higher extinction coefficient of the $d-d$ band for the activecopper (II) species relative to the starting complex. Further, the added molecular oxygen competes strongly with step 2 of the proposed reaction cycle and keeps most of the copper in the oxidized state. This has direct impact on the yields of the two products, viz. aldehyde and acetophenone, that drop dramatically; the aldehyde yield decreases by $80 \%$ while the ace- 

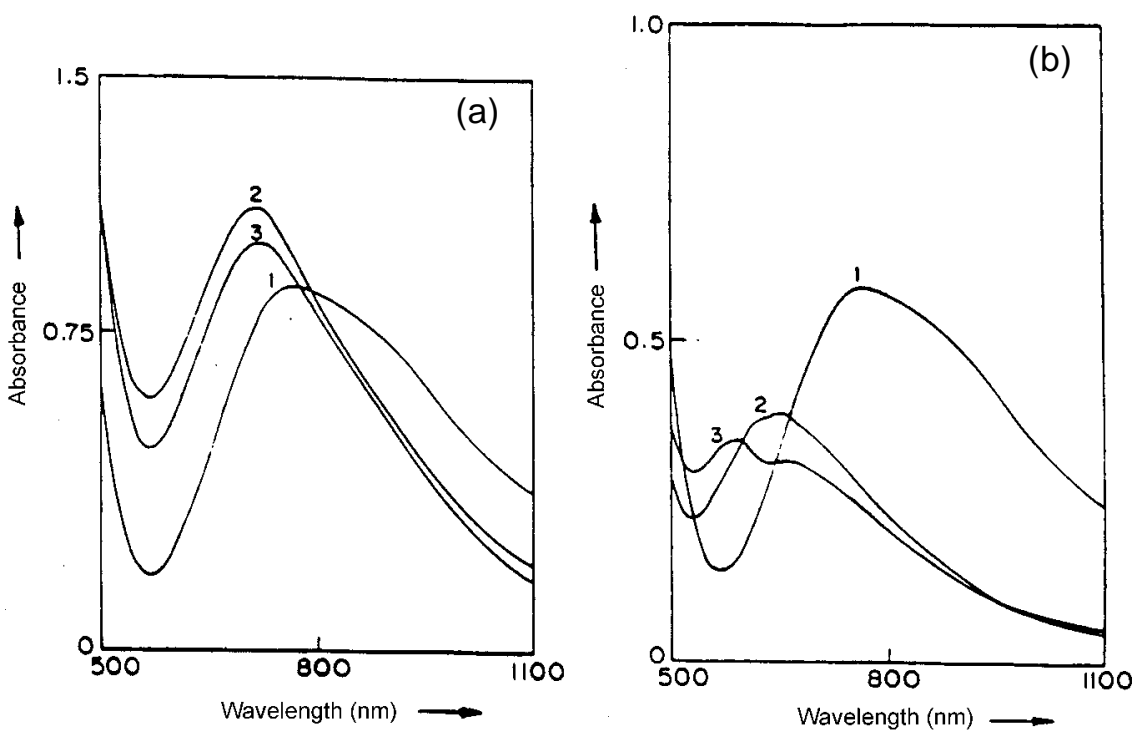

Figure 16. (a) Curve 1: $d-d$ band spectrum of a reaction mixture $(0 \cdot 0308 \mathrm{mmol}$ of $[\mathrm{CuCl}(\mathrm{O}-\mathrm{GBHA})] \mathrm{Cl}, 0 \cdot 616 \mathrm{mmol}$ of 4-chlorobenzyl alcohol, $0 \cdot 616 \mathrm{mmol}$ of cumenyl hydroperoxide) under $\mathrm{O}_{2}$ at the time of mixing. Curve $2: d-d$ band spectrum of a reaction mixture $1 \mathrm{~h}$ after the initiation reaction. (b) Curve 1: $d-d$ band spectrum of a reaction mixture $(0.0308 \mathrm{mmol}$ of $[\mathrm{CuCl}(\mathrm{O}-\mathrm{GBHA})] \mathrm{Cl}, 0.616 \mathrm{mmol}$ of 4-chlorobenzyl alcohol, $0.616 \mathrm{mmol}$ of cumenyl hydroperoxide, $0.308 \mathrm{mmol}$ of TBHP) at the time of mixing. Curve 2: $d-d$ band spectrum of a reaction mixture after $30 \mathrm{~min}$ of heating. Curve 3: $d-d$ band spectrum of a reaction mixture $1 \mathrm{~h}$ after the initiation of reaction.

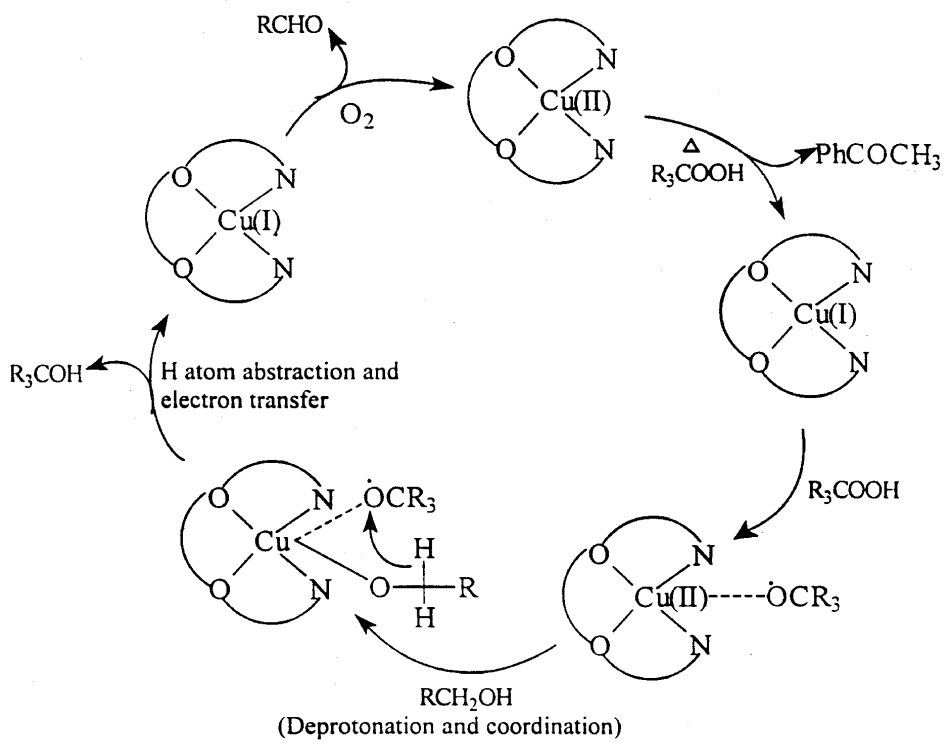

Figure 17. Proposed catalytic reaction cycle.

tophenone by $46 \%$, indicating severe competition by oxygen in steps 2 and 3 of the reaction cycle.

The generation of cumylperoxyl radicals during the course of the present reaction is confirmed by the identification of acetophenone as one of the reaction products. Further, when a radical trap like 2,4,6-tri$t$-butylphenol $(0.308 \mathrm{mmol}, \mathrm{TBHP})$ is included in the reaction mixture and the reaction is carried out as indicated under the oxidation of alcohols (with vigorous exclusion of oxygen), it is found that a new band at $\sim 640 \mathrm{~nm}$ generate is after the reaction has been thermally activated for $30 \mathrm{~min}$. This supports the formation of the stable 2,4,6-tri-t-butylphenoxy radical $^{22}$ via the oxidation of TBHP by cumylperoxyl radicals (figure 16b).

The yield of the aldehyde and acetophenone obtained after workup of the reaction indicates a drop of $74 \%$ for the ketone (table 2). This implies that the 
presence of the radical trap severely inhibits step 3 relative to step 1 of the proposed reaction cycle. This further justifies the presence and the utilization of cumylperoxyl radical in the oxidation of 2,4,6-tri- $t$ butylphenol to the phenoxy radical.

The proposed catalytic reaction cycle is depicted in figure 17. This reactivity is reminiscent of the functioning of copper site in the enzyme galactose oxidase.

Thus the present series of bis-benzimidazole diamide $\mathrm{Cu}(\mathrm{II})$ complexes are capable of activating the peroxyl group and molecular oxygen.

\section{Acknowledgement}

We gratefully acknowledge financial support from the Department of Science and Technology, Govt. of India.

\section{References}

1. Solomon E I, Baldwin M J and Lowery M D 1992 Chem. Rev. 92521

2. Klabunde T, Eicken C, Sacchettini J and Krebs B 1998 Nat. Struct. Biol. 51084

3. (a) Klinman J P 1996 Chem. Rev. 96 2541; (b) Whittaker J W and Whittaker M M 1998 Pure Appl. Chem. 70 903; (c) Whittaker J W and Sigel A 1994 Met. Ions Biol. Syst. 30315

4. Whittaker M M, De Vito, V L, Asher S A and Whittaker J W 1989 J. Biol. Chem. 2647104

5. (a) Ito N, Philips S E V, Stevens, C, Orgel Z B, Mc Pherson M J, Keen J N, Yadav K D S and Knowles P F 1991 Nature (London) 350 87; (b) Ito N, Philips S E V, Yadav K D S and Knowles P F 1994 J. Mol. Biol. 238794

6. Anson F C, Collins T J, Richmond T G, Santarsiero B D, Toth J E and Treco B G R T 1987 J. Am. Chem. Soc. 1092974

7. Koikawa M, Okawa H, Maeda Y and Kida S 1992 Inorg. Chim. Acta $1992 \mathbf{1 9 4 7 5}$

8. (a) Redmore S M, Rickard C E F, Webb S J and Wright L J 1997 Inorg. Chem. 36 4743; (b) Patra A K, Roy M and Mukherjee R 1999 J. Chem. Soc., Dalton Trans. 2461; (c) Kawamoto T, Hammes B S, Ostrander R, Rheingold A L and Borovik A S 1998 Inorg. Chem. 373424

9. Gupta M, Mathur P and Butcher R J 2001 Inorg. Chem. 40 8(b); Gupta M, Das S K, Mathur P and Cordes A W 2003 Inorg. Chim. Acta 353 197; (c) Gupta M, Upadhyay S K, Sridhar M A and Mathur P 2006 Inorg. Chim. Acta 359 4360; (d) Tehlan S, Hundal, M S and Mathur P 2004 Inorg. Chem. 436589
10. Barnes D J, Chapman R L, Vagg R S and Watton E C 1978 J. Chem. Eng. Data 23349

11. McKee V, Zvagulis M, Dagdigian J V, Patch M G and Reed C A 1984 J. Am. Chem. Soc. 1064765

12. (a) Tandon S S, Thompson L K, Bridson J N and Dewan J C 1994 Inorg. Chem. 33, 54; (b) Addison A W, Burke P J, Henrick K, Rao T N and Sinn E 1983 Inorg. Chem. 22 3645; (c) Hendricks H M J, Birker P J M W L, Rijn J V, Verscoor G C and Reedijk J J 1982 Am. Chem. Soc. 104 3607; (d) Reitmeijer F J, Birker P J M W L, Gorter S and Reedijk J 1982 J. Chem. Soc., Dalton Trans. 1193 (e) Rao T N and Addison A W 1984 J. Chem. Soc., Dalton Trans. 1349

13. (a) Lloret F, Julve M, Faus J, Journax Y, Levisalles M P and Jeannin Y 1989 Inorg. Chem. 283702 (b) Lloret F, Julve M, Faus J, Ruiz R, Castro I, Mollar M and Levisalles M P 1992 Inorg. Chem. 31 784; (c) Frances L, Julve M, Real J, Faus J, Ruiz R, Mollar M, Castro I and Bois C 1992 Inorg. Chem. 31 2956; (d) Lloret F, Sletten J, Ruiz R, Julve M, Faus J and Verdauger M 1992 Inorg. Chem. 31778 (e) Sangeetha N R, Baradi K, Gupta R, Pal C K, Manivannan V and Pal S 1999 Polyhedron 1999181425

14. Vezzosi I M and Antolini I 1984 Inorg. Chim. Acta 85155

15. (a) Prochaska H J, Shwindinger W F, Schwartz M, Burk M J, Bernarducci E, Lalancette R A, Potenza J A and Schugar H J $1981 \mathrm{~J}$. Am. Chem. Soc. 103 3446; (b) Prout C K, Allison G B and Rassottii F J C 1971 J. Chem. Soc. A, 3331; (c) Camerman N, Fawett J K, Kruck T P A, Sarkar B and Camerman A 1978 J. Am. Chem. Soc. 100 2690; (d) Jaffery V, Dagdigian V M and Reed C A 1982 Inorg. Chem. 21 1332

16. Thompson L K, Ramaswamy B S and Seymour E A 1977 Can. J. Chem. 55878

17. (a) Monzani E, Battani G, Perotti A, Casella L, Gulloti M, Santagostini L, Nardin G, Randaccio L, Geremia S, Zanello P and Opromolla G 1999 Inorg. Chem. 38 5359; (b) Bolus D and Vigee G S 1982 Inorg. Chim. Acta 67 19; (c) Zippel F, Ahlers F, Werner R, Haase W, Nolting H F and Krebs B 1996 Inorg. Chem. 353409

18. Cook C D and Norcross B E 1959 J. Org. Chem. 811170

19. (a) Chin D, La Mar G N and Balch A L $1980 \mathrm{~J}$. Am. Chem. Soc. 102 5945; Balch A L (Private Communication (b) Arasasingham R D, Balch A L and LatosGrazynski L 1987 J. Am. Chem. Soc. 5846

20. Fukuzumi S and Ono Y 1979 Bull. Chem. Soc. Jpn. 522255

21. Fukuzumi S and Ono Y 1977 J. Am. Chem. Soc., Perkin Trans. 2622

22. (a) Palaniandavar M, Pandiyan T and Laksminarayanan M 1995 J. Chem. Soc., Dalton Trans. 457 (b) Nonoka Y, Tokh T and Kida S 1974 Bull. Chem. Soc. Jpn. 2312

23. Batra G and Mathur P 1992 Inorg. Chem. 311575

24. Cook C D and Norcross B E $1958 \mathrm{~J}$. Am. Chem. Soc. 811176 